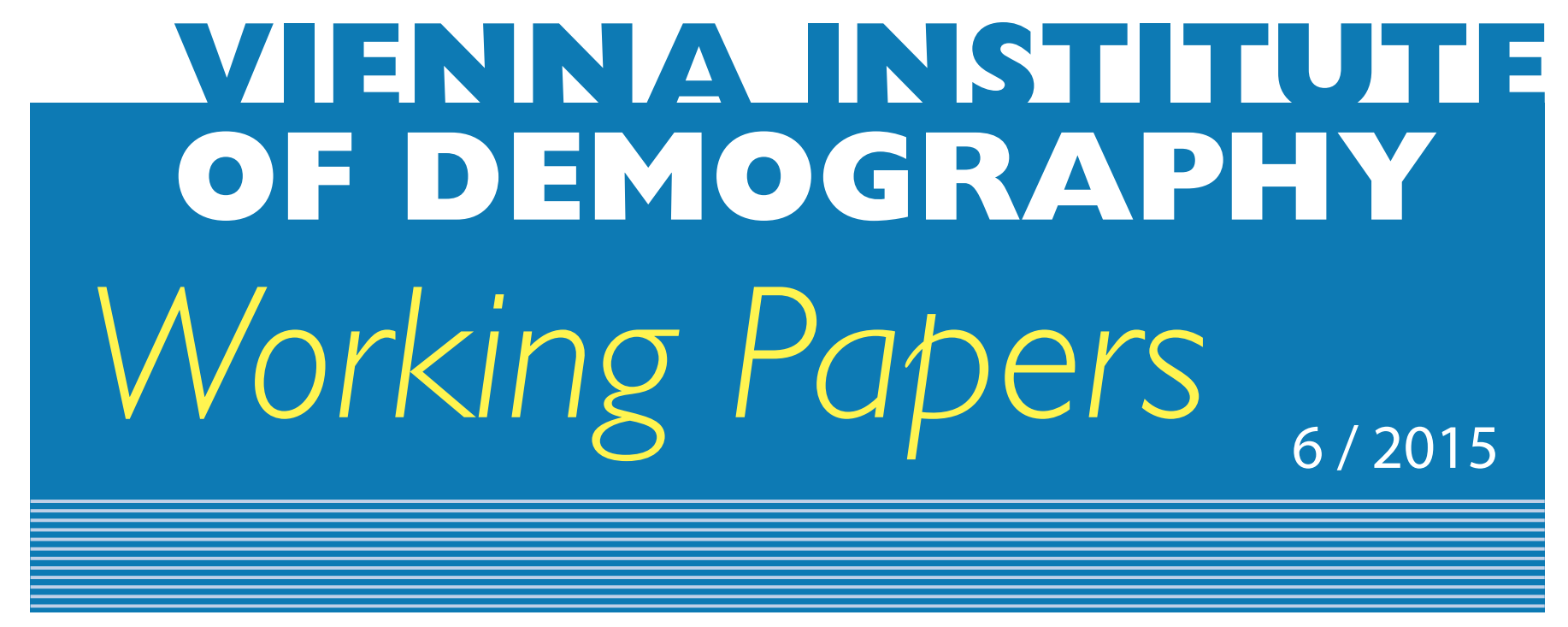

Eva Beaujouan, Zuzanna Brzozowska and Kryštof Zeman

\title{
Childlessness Trends in \\ Twentieth-Century Europe: \\ Limited Link to Growing \\ Educational Attainment
}

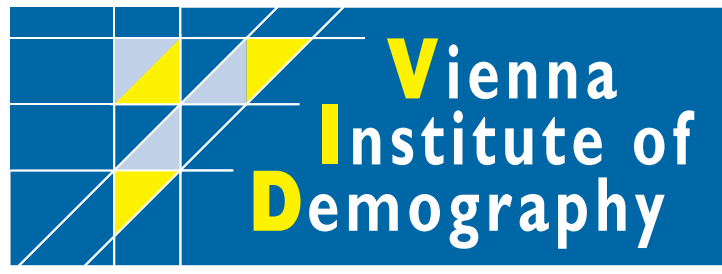

Vienna Institute of Demography Austrian Academy of Sciences

Wohllebengasse 12-14

A-I040 Vienna · Austria

E-Mail:vid@oeaw.ac.at

Website: www.oeaw.ac.at/vid 


\begin{abstract}
Childlessness, a driving force of fertility, has undergone strong variations in 20th-century Europe, and educational attainment has been rising continuously. We analyse how these two factors were related to each other over time. Our study is based on census and largescale survey data from 13 European countries, collected in the Cohort Fertility and Education database. We compare the trends in the share of women childless at age 40+ in the 1916-1965 birth cohorts, by level of education. The results suggest that the changes in the educational composition of the population were only marginally related to the overall variation in childlessness rates. With time, the positive educational gradient in childlessness usually decreased: the differences between women of medium/high education and low educated women diminished. However, the childlessness ratio between highly and medium educated women remained stable in Western and Southern Europe and even slightly increased in the East.
\end{abstract}

\title{
Keywords
}

Childlessness, cohort fertility, education, trends, Eastern and Western Europe

\section{Authors}

Eva Beaujouan (corresponding author), Wittgenstein Centre (IIASA, VID/ÖAW, WU), Vienna Institute of Demography/Austrian Academy of Sciences. Email: eva.beaujouan@oeaw.ac.at

Zuzanna Brzozowska, Wittgenstein Centre (IIASA, VID/ÖAW, WU), Vienna Institute of Demography/Austrian Academy of Sciences, and Warsaw School of Economics. Email: zuzanna.brzozowska@oeaw.ac.at

Kryštof Zeman, Wittgenstein Centre (IIASA, VID/ÖAW, WU), Vienna Institute of Demography/Austrian Academy of Sciences. Email: kryštof.zeman@oeaw.ac.at

\section{Acknowledgements}

This research was funded by the European Research Council under the European Union's Seventh Framework Programme (FP7/2007-2013) / ERC Grant agreement no. 284238 (EURREP project). Results of the study have been presented at the 2014 British Society for Population Study annual conference in Winchester. We thank the EURREP team, and particularly Tomáš Sobotka, who provided comments on an earlier draft of this study. 


\title{
Childlessness Trends in Twentieth-Century Europe: Limited Link to Growing Educational Attainment
}

\author{
Eva Beaujouan, Zuzanna Brzozowska and Kryštof Zeman
}

\section{Introduction}

The 20th century brought countless fundamental changes to women's lives. Among those, growing educational attainment and labour force participation, together with effective fertility control are considered of primary importance for changes in fertility (Bianchi and Milkie 2010; Brewster and Rindfuss 2000; Murphy 1993). However, the forces behind the trends in childlessness, a fundamental component of fertility, remain largely underexplored. Undoubtedly, in the first half of the century, childlessness was largely affected by the wars, the great economic depression and the still poor health conditions, and in the later period both by new life aspirations and hormonal contraception (Kreager 2004; Rowland 2007; Tanturri and Mencarini 2008; Tanturri et al. 2015; Van Bavel and Reher 2013). Was rising educational attainment another factor that contributed to the share of ultimately childless women?

Among European women born in the 20th century, ultimate childlessness varied greatly across time and regions. It universally declined until the 1940s birth cohorts; then it tended to stabilise in the state-socialist countries and to rise again in the West (Frejka and Sardon 2004; Miettinen, Rotkirch, Szalma, Donno, and Tanturri 2015; Sobotka 2012; van Agtmaal-Wobma and van Huis 2008). In contrast, female enrolment in education went up continuously across all Europe, starting in the first half of the century (Barro and Lee 2013; Breen, Luijkx, Müller, and Pollak 2009; Goujon 2009). An increasing number of women gained secondary education, outnumbering those with basic or no education; university education became more and more popular as well, but at slower pace. Given the contextual change, the prevalence of childlessness possibly changed across all the educational strata over the century. Additionally, the expansion of the medium- and high-educated groups might have mechanically affected the overall percentage of childless women, as well as the share of women remaining childless within the educational groups.

Studies on trends in childlessness taking education into account have mostly confined their analyses either to baby boomers or to a specific region or country (Andersson et al. 2009; Köppen, Mazuy, and Toulemon 2007; van Agtmaal-Wobma and van Huis 2008; Van Bavel 2014). A European overview of changes over a long time-span, which would help understand the observed diversity in childlessness, is lacking. Our paper provides such a study, based on censuses and large-scale surveys from 13 European countries. It investigates the macro-level relationship between education and ultimate childlessness and its variation across the 1916-1965 birth cohorts (which correspond to the period between the 1940s and early 2000s). By choosing this time span we cover both the early period of universal decline in the proportion of childless women and the later diversification across regions. We compare countries from both sides of the Iron Curtain, 
which makes our study a unique portrait of trends in childlessness and education, and their interplay on the long-divided continent.

\section{Childlessness and Education}

Researchers generally expect a positive aggregate relationship between level of education and cohort childlessness, certainly due to the strong evidence of a positive association between childlessness and education at individual level (Bloom and Trussell 1984; González and Jurado-Guerrero 2006; Nicoletti and Tanturri 2008). A positive educational gradient in childlessness can be observed in the UK and the US (Berrington, Stone, and Beaujouan 2014; Hayford 2013; Kneale and Joshi 2008) and also in the German-speaking countries apart from East Germany (Sobotka 2012). Also in France women with high education tend to have children less often than those with low education (Köppen et al. 2007; Masson 2013). However, evidence from Northern Europe shows that the gradient can change over time and can vary in steepness (Andersson et al. 2009). For instance, the gradient is much more pronounced in Norway than in Denmark, where the difference between the low- and medium-educated born in the 1950s disappeared. In the 1955-59 birth cohort in Finland and Sweden, the education-childlessness relationship shows a U-shape, with the medium-educated exhibiting the lowest levels of childlessness and the low educated the highest (Andersson et al. 2009). Finally, among the countries participating in the Generations and Gender Programme, Wood et al. (2014) showed that the educational gradient of childlessness was very weak in Belgium, Russia, Hungary and Estonia. They also found that despite the large educational changes, the shape of the gradient between low, medium, and high education was very stable between the 1940-44 and the 1956-61 birth cohorts in each of those countries.

The purpose of this article is to provide a comprehensive description of the educational differences in ultimate childlessness and their variation across cohorts and countries from the East and West of Europe.

\subsection{Trends in Childlessness and Education}

Several studies have documented cross-country trends in ultimate childlessness for the 20th century (Frejka 2008; Rowland 2007; Sardon 2002). Cohorts of women born at the beginning of the 20th century give a striking example of high childlessness prevalence, despite the absence of effective birth control at that time (Morgan 1991). In Northern and Western Europe, and in Italy, childlessness was reaching up to 25-30\% (Rowland 2007); in the Czech Republic and probably in Romania it also exceeded 20\% (Frejka 2008). Until around the 1940 birth cohort, on both sides of the Iron Curtain, childlessness figures decreased steeply. During the baby boom, i.e. the time of universal (and early) marriage and childbearing, they went down to between 10-15\% and 5\%-10\% on the Western and Eastern side of the Iron Curtain, respectively. Then they began to develop differently in the capitalist and state-socialist countries. In the former area, childlessness started to rise again quickly, varying in the 1960 birth cohort from 10\% in Greece and Spain to 20\% in Germany (Miettinen et al. 2015; Sobotka 2012). In the state-socialist countries, 
childlessness usually kept declining and then levelled off, oscillating around 6-8\% between the 1950s and the early 1960s birth cohorts, when it began to increase at various paces (Frejka 2008).

The trends described above were accompanied by a massive expansion of secondary education. The share of women finishing their education at primary level shrank continuously and over time more than one-half had at least secondary education in all European countries (Barro and Lee 2013; Breen et al. 2009; Goujon 2009). The mediumeducated constituted the largest educational group, so their fertility had become a driving element of overall fertility levels by the end of the 20th century (Kreyenfeld and Konietzka 2008). In a parallel development, high education spread continuously as well, albeit rather slowly, and in most countries the share of university degree holders among women born at the beginning of the 1960s did not exceed 20\% (Breen et al. 2009; OECD 2014).

\subsection{Link between Education and Childlessness}

The educational expansion among women could have affected childlessness levels in various ways. On the one hand, if the educational differences in childlessness remained constant over time (in other words, if women in all educational groups retained their childlessness rates relative to the other groups), the overall level of childlessness would have been directly influenced by the educational composition of the population. On the other hand, the reshaping of educational groups, together with changes in behaviour of women within each educational group, could have moderated the compositional effect by altering the educational gradient.

For instance, when expanding rapidly, the group of the medium-educated absorbed people of less educated background together with their values and lifestyles. Previous research has documented intergenerational transmission of fertility through childhood socialisation and the passing on of parents' ideals to children (Anderton, Tsuya, Bean, and Mineau 1987; Kolk 2014; Preston 1976). According to the acculturation hypothesis, which has been proved by Blau and Duncan (1967), and then by Sobel $(1981,1985)$, those who achieve a higher socioeconomic status than their parents will only partially conform to the norms and values of their new strata, including those concerning family formation. If this mechanism holds here, levels of childlessness among the medium-educated could become more similar to those seen among the least educated as the group expands.

As another example, during the baby boom, highly educated women changed their childbearing behaviour so that their increasing percentage did not result in lower overall fertility (Sandström 2014; Van Bavel 2014). In times when the share of the highly educated was very small, university degree holders formed a highly selected group of women coming mostly from very specific families with substantial intellectual and economic resources. When the group slowly expanded, i.e. absorbed people from less educated backgrounds, it may have lost some of its distinctiveness (Goldin 2004). In regard to childlessness, which is usually higher among the most educated, the spread of high education could thus have resulted in lower levels in this group. At the other end of the spectrum, women with low education by becoming less and less numerous could have 
started displaying specific childlessness behaviours, as they do for extra-marital childbearing (Perelli-Harris et al. 2010).

Carefully studying the compositional change in the female population and analysing the contribution of the various educational groups to the overall level of childlessness will help disentangle their role in the fluctuating childlessness rates over the century. We examine the largely unexplored developments in childlessness and female education by answering the following two questions. First, have the levels of childlessness among women with medium and low education become more similar with time? Second, did childlessness among highly educated women lose its distinctiveness as that group became less select?

\subsection{Childlessness in the East and in the West}

As pointed out above, women born at the turn of the 20th century quite often stayed childless. This was partly driven by high age at marriage and generally low marriage rates, but also by delayed childbearing even among married women, often attributed to the wars and economic circumstances (Morgan 1991; Rowland 2007). Historical studies found that postponing marriage and delaying childbearing within marriage were socially accepted strategies especially in times of economic pressure, at least in Northern and Western Europe and in the US (Rowland 2007). The great male losses of World War I and the dramatic economic situation during the Great Depression caused many women to postpone or forgo marriage and motherhood (Morgan 1991; Rindfuss, Morgan, and Swicegood 1988), which is reflected in the statistics: for France and the US, it has been estimated that around $16.5 \%$ and $20 \%$, respectively, of ever-married women born in the 1900s remained childless (Morgan 1991; Toulemon 1996). Much less is known about central and Eastern Europe (see Szołtysek 2012 for a discussion of the consequences of the missing data on this region) but family norms there seemed essentially similar to those seen in the West.

The end of World War II brought socio-economic changes that allowed a more universal access to matrimony and reproduction. In the West, post-war prosperity, together with its high male wages, an emerging middle-class society and new household appliances easing everyday life, largely supported the male-breadwinner family model (Coontz 2000). On both sides of the Iron Curtain, people caught up on marriages and parenthood postponed by the Great Depression and the war. A general expectation was to marry early and have children quickly. Voluntarily childless marriages were perceived as egoistic, selfindulgent and avoiding social responsibility (Jurgen Dorbritz and Fleischhacker 1999; Dykstra and Hagestad 2007). In surveys conducted in the 1960s, almost $70 \%$ of the respondents in the Netherlands and over $80 \%$ in the US did not accept voluntary childlessness of married couples (Dykstra and Hagestad 2007).

The socialist countries in Europe did not experience prosperity in the Western European sense, but they still enjoyed a massive economic growth (Berend 2005). While the Western democracies experienced the beginning of great social changes in the late 1960s, commonly described as individualisation (Inglehart 1971; van de Kaa 1996, 2004), these were less visible behind the Iron Curtain. In regimes which vigorously fought 
individualism and actively promoted sexual puritanism and conservative gender roles, post-materialistic values could not have progressed much (Sobotka 2008). The spread of the Second Demographic Transition (SDT), though it temporarily emerged at places (Hoem, Kostova, Jasilioniene, and Mureşan 2009; Sobotka, Zeman, and Kantorová 2003; Spéder and Kamarás 2008), was hindered by social policies that supported the traditional family consisting of a married couple with children (Keil and Andreescu 1999; McIntyre 1975). For instance, except in East Germany single mothers or childless couples had very small chance of getting their own apartment (Sobotka 2011).

The post-war boom in starting families was not pronounced in the East, but fertility was higher than in the West until the end of state-socialism (Sobotka 2011). As governments believed in a direct link between national power and population size, procreation was proclaimed as the duty of every loyal citizen (Dorbritz and Fleischhacker, 1999) and supported by strong pronatalist policy measures (Frejka 1980; Haney 2002; Stloukal 1999). The most oppressive ones were introduced in Ceaușescu's Romania, where abortion was illegal, contraceptives unavailable, and singles and childless couples over age 25 had to pay an extra tax (Baban 1999). The pressure on having children also came from people's families, who played a much more important role in young grown-ups' lives than in the West: in the shortage economies, the unofficial distribution channels, i.e. through acquaintances and family bonds, were of primary importance. These mutual dependencies made one ready to conform to socially expected behaviour (Giza-Poleszczuk 2007).

We study the question of the East-West differences in cohort childlessness over the century. We compare not only the overall trends, but also the educational gradients. For cohorts born at the beginning of the century we expect similar educational differences in the East and West. For women born in the 1930-1950s, we expect gradients to be generally smaller on the Eastern side of the Iron Curtain, since reproductive careers took place mainly under state-socialism when women had rather standard options with regard to family and career trajectories. We are aware, however, that in some CEE countries this rule might not hold, as education strongly stratified childlessness, and educational expansion played a very important role in fertility changes (Brzozowska 2014).

\section{Data and Methods}

We use data from censuses that cover five-year female cohorts from 1916-20 to 1956-60 aged 40 to 76 in the following countries: Austria (Censuses 1991, 2001), Croatia (2001, 2011), the Czech Republic (1980, 2001, 2011), France (1982, 1990, 1999 and 2011), Germany (Microcensus 2008, 2012), Hungary (1990, 2001), Italy (Family and Social Subjects 2003, 2009), Poland (a survey accompanying the 2002 census), Romania (1992, 2002), Slovakia (2001), Slovenia (2002), Spain (2011), and Switzerland (2000). Data for Hungary, Romania and Slovenia were originally derived from IPUMS International (Minnesota Population Center 2013 ${ }^{1}$ ) and were 5\% (Hungary) and 10\% (Romania and Slovenia) census samples. For comparability, we use a three-category classification of

\footnotetext{
${ }^{1}$ Data originally produced by: Hungarian Central Statistical Office, Romanian National Institute of Statistics, Statistical Office of the Republic of Slovenia.
} 
education: low, medium and high, which in most cases correspond to ISCED-97 levels 02, 3-4, 5-6, respectively. For a translation of national school levels to ISCED-97, see Table A1 in Appendix. These data were collected within the EURREP project and are also part of the Cohort Fertility and Education database ${ }^{3}$ (Zeman, Brzozowska, Sobotka, Beaujouan, and Matysiak 2014).

Besides the quality checks made during the construction of the database, specific checks show very consistent childlessness trends in the countries covered, and only two issues can be risen. First, in the Czech Republic low educated show higher levels of childlessness relative to middle educated, which is not seen in other countries. The absolute difference is however very small, due to very low levels of childlessness in this country, and thus the strong relative contrast reflects very small absolute differences. Additionally, as the group with low education now represents less than $10 \%$ of the population, strong selection effects might prevail. Second, in France the ISCED grouping that we have adopted does not seem to match the grouping usually displayed in OECD studies: the share of the highly educated is here twice as small as usually shown (OECD 2014). However, the definition and levels displayed are comparable with those of the other countries in this study. Finally, register data from the Northern Europe countries are absent from our analysis, but we refer to the study by Andersson et al. (2009) that compares childlessness rates by level of education in Finland, Norway, Sweden and Denmark.

First, we analyse the cohort trends in educational structure in all the countries. Then we compile childlessness rates among women by cohort and level of education. We also compare the educational structure of childless women and of the overall population, to evaluate the educational gradient in childlessness. By calculating the following relative childlessness index for each country we assess the educational gradient relative to women with medium education in childlessness over time:

$$
\frac{F_{e}^{0}}{F_{e}} / \frac{F_{\text {medium }}^{0}}{F_{\text {medium }}}
$$

where $\frac{F_{e}^{0}}{F_{e}}$ and $\frac{F_{\text {medium }}^{0}}{F_{\text {medium }}}$ denote the share of childless women among women with education $e$ and with medium education, respectively, with $e$ standing for the level of education.

Further, we aim to understand whether the trends in childlessness were driven by the changing educational structure of the female population or by changes in childlessness rates within the educational sub-groups. We thus conduct direct (at constant educational levels, Equation 2a) and indirect standardisation (at constant share of childless women in each educational group, Equation 2b). The 1936-40 cohort is chosen as the standard because it was the one for which childlessness reached minimum in most countries.

\footnotetext{
${ }^{2}$ ISCED stands for International Standard Classification of Education developed by UNESCO. For more information, please visit http://www.uis.unesco.org/Education/Pages/international-standard-classification-ofeducation.aspx.

${ }^{3}$ CFE database, http://www.cfe-database.org
} 


$$
\begin{array}{r}
C h L_{\text {direct }}(t+h)=\sum_{e}\left[\frac{F_{e}(t)}{F(t)} * \frac{F_{e}^{0}(t+h)}{F_{e}(t+h)}\right] \\
C h L_{\text {indirect }}(t+h)=\sum_{e}\left[\frac{F_{e}(t+h)}{F(t+h)} * \frac{F_{e}^{0}(t)}{F_{e}(t)}\right],
\end{array}
$$

where $C h L$ is the proportion of childless women in the female population, $t$ is constant and corresponds to the 1936-40 birth cohort, while $h$ denotes five-year cohorts, starting from 1916-20 and ending with 1956-60; $\frac{F_{e}}{F}$ equals the proportion of women with education $e$ in the female population.

Finally, we compute the relative differences $\left(D_{r e l}\right)$ between the standardised values of childlessness and the real ones, applying the following formula:

$$
D_{\text {rel }}(t+h)=\frac{C h L^{*}(t+h)-C h L(t+h)}{\operatorname{Ch} L(t+h)}
$$

where $C h L^{*}(t+h)$ denotes the standardised $\operatorname{Ch} L(t+h)$ as given in Equation $2 \mathrm{a}$ and $2 \mathrm{~b}$, and $C h L(t+h)$ equals $\frac{F^{0}(t+h)}{F(t+h)}$.

\section{Results}

\subsection{Educational Differences in Childlessness}

In line with the existing analyses of educational expansion, between the birth cohorts 1916 and 1960 the main shift in educational structure concerned the women with low and medium education, whose percentages inverted (Figure 1). In most countries, the switch took place among women born in the 1940s and the early 1950s, but in Switzerland and the Czech Republic it had already taken place in the 1931-35 birth cohort, while in Italy and Romania it came with a ten-year delay. In the West, women in Italy, France and Spain originally had lower levels of education than in the German-speaking countries but afterwards were faster in their educational transition. In the East, Hungary and Romania were particularly slow in their transition, while Poland, Slovakia and the Czech Republic were very fast.

The share of women with high education, well below 5\% everywhere in the earliest cohorts, increased almost linearly but usually at a slower rate than that of mediumeducated. Only in Germany, Switzerland and Slovenia the two curves went up parallel. In the last cohort observed (1961-65), the proportion of highly educated women did not exceed $20 \%$ except in Spain. It is only in the recent period that high education spread very quickly (OECD 2014, table A1-4a) and this is not yet visible in the cohorts presented here.

The proportion of ultimately childless women varied substantially both over time and by region, but the early trends were common to most of the analysed countries (Figure 2). Indeed, among women born before the 1940s (and before the 1950s in Croatia and Romania), childlessness was decreasing. In countries where it was already low (around 5\% for Slovakia, $10 \%$ for the Czech Republic and Croatia) it changed little over time, but in those with high childlessness rates the fall was fairly sharp (e.g. from 20 to $10 \%$ in twenty years in Romania). From the 1940s birth cohorts onward, the share of childless women 
either started to increase (Austria, West Germany, Switzerland, Spain, and Croatia, and more slowly in Slovakia and France) or it stabilised (Romania) or further decreased (Hungary, Poland, and Slovenia), at least in the cohorts observed. In the German-speaking countries it went up significantly earlier, and faster, than in the other countries.

The trends in childlessness within the educational groups were generally coordinated with the general trends. In the phase of decrease however, the educational gradient in childlessness of high versus low educated women diminished consistently in all countries except in Romania (Figure A1 in Appendix): levels of childlessness of high- and loweducated women became closer. This was however linked to both a convergence in the levels of childlessness of low and medium educated women and a stable-even increasing in the East — gradient between medium and high educated, that we detail here.

Figure 3 compare childlessness among women with low/high education with that among the medium-educated in the East and West of Europe. In all the countries analysed except for Croatia, childlessness rates of low- and medium-educated women became more and more similar: while in the oldest cohorts childlessness among the least-educated was twice as small as among the medium-educated, in the more recent cohorts the difference (almost) vanished (though in some countries like Switzerland the least educated still were $25 \%$ less likely to remain childless. ${ }^{4}$ ) Possibly, in countries with a massive expansion of medium education, i.e. with great upward social mobility, women with medium education gradually tended to resemble those with low education. On the other hand, this mechanism does not seem to have fully worked: in several countries (particularly in the Germanspeaking countries), medium-educated women eventually remained childless slightly more often than less educated women. This is the case of Austria, Switzerland, Germany, and Italy, and of Croatia and Romania.

In contrast with the convergence between low- and medium-educated women, childlessness among women with high education remained constantly higher than among those with medium education. This relative difference in childlessness was rather stable in the West but increased in the East, from one and a half times to twice (Figure 3). Only in France, Slovakia, and the Czech Republic did the relative childlessness level of highly versus medium-educated women decrease in the youngest cohorts. Although the share of women with university degrees grew with time and the levels of childlessness among them shrank, highly educated women thus remained highly specific in being childless, and grew even more different in most of the East-where the overall level of childlessness is very low, however.

\footnotetext{
${ }^{4}$ In the Czech Republic the relationship reversed and childlessness levels of women without a degree became twice as high as among women with intermediate education, but the levels of childlessness were very low (see comment in section 3).
} 
Figure 1 Educational composition of the population in each country-women born 1916-1960
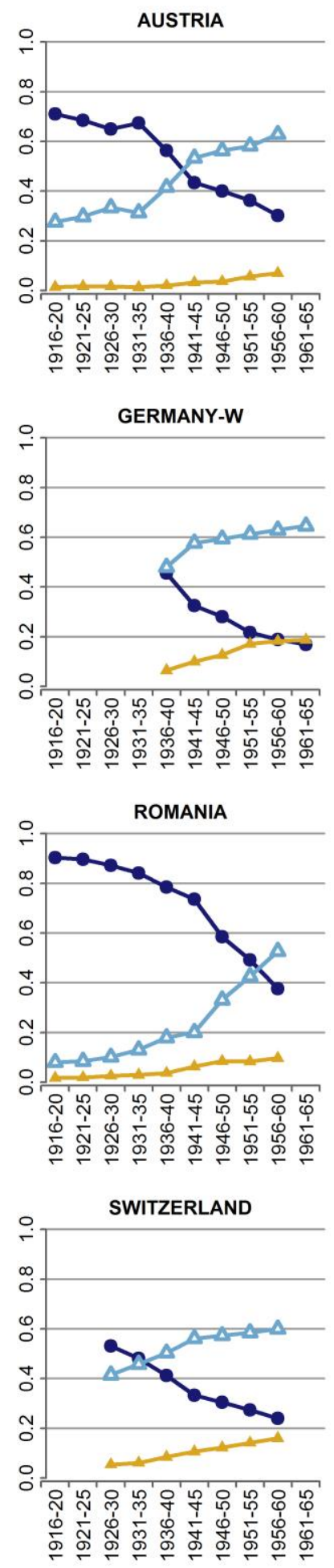
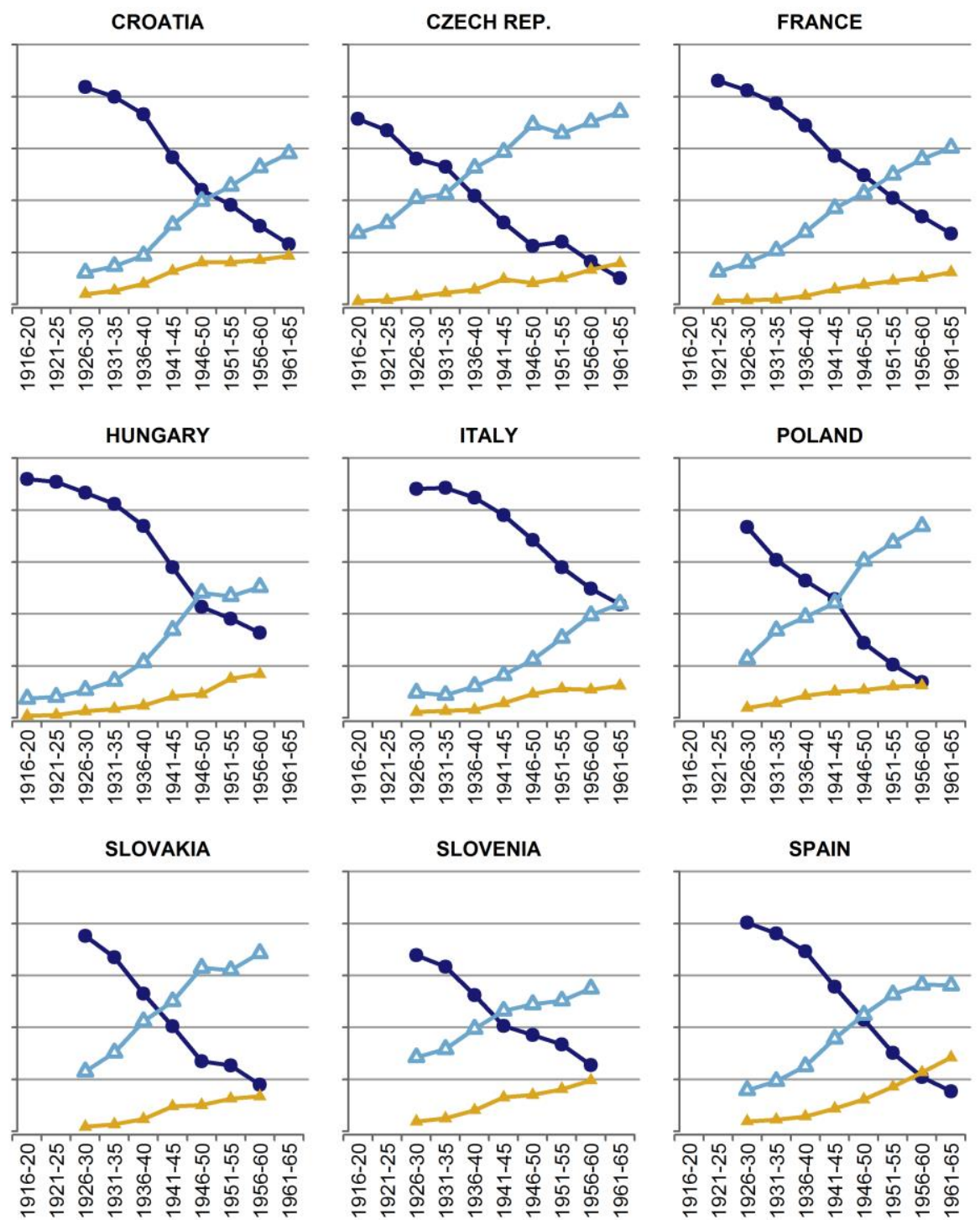
Figure 2 Proportion of childlessness by level of education in each country-women born 1916-1960
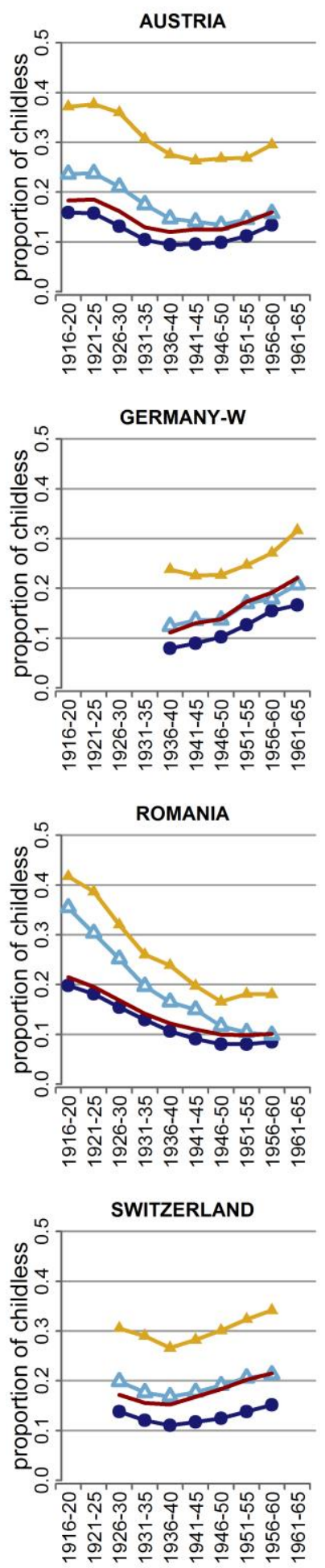
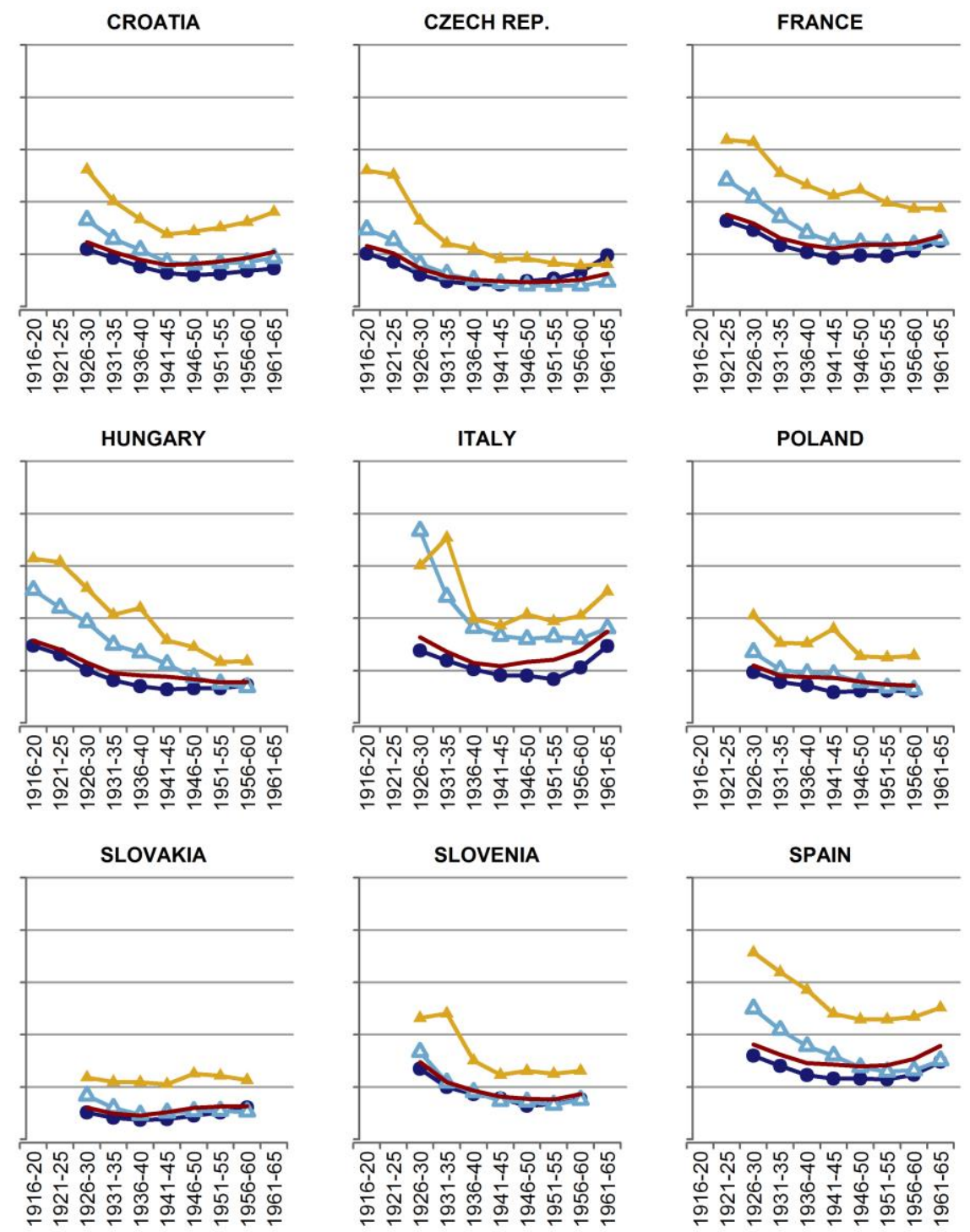
Figure 3 Relative childlessness index, representing childlessness level relative to childlessness of medium-educated women in each country
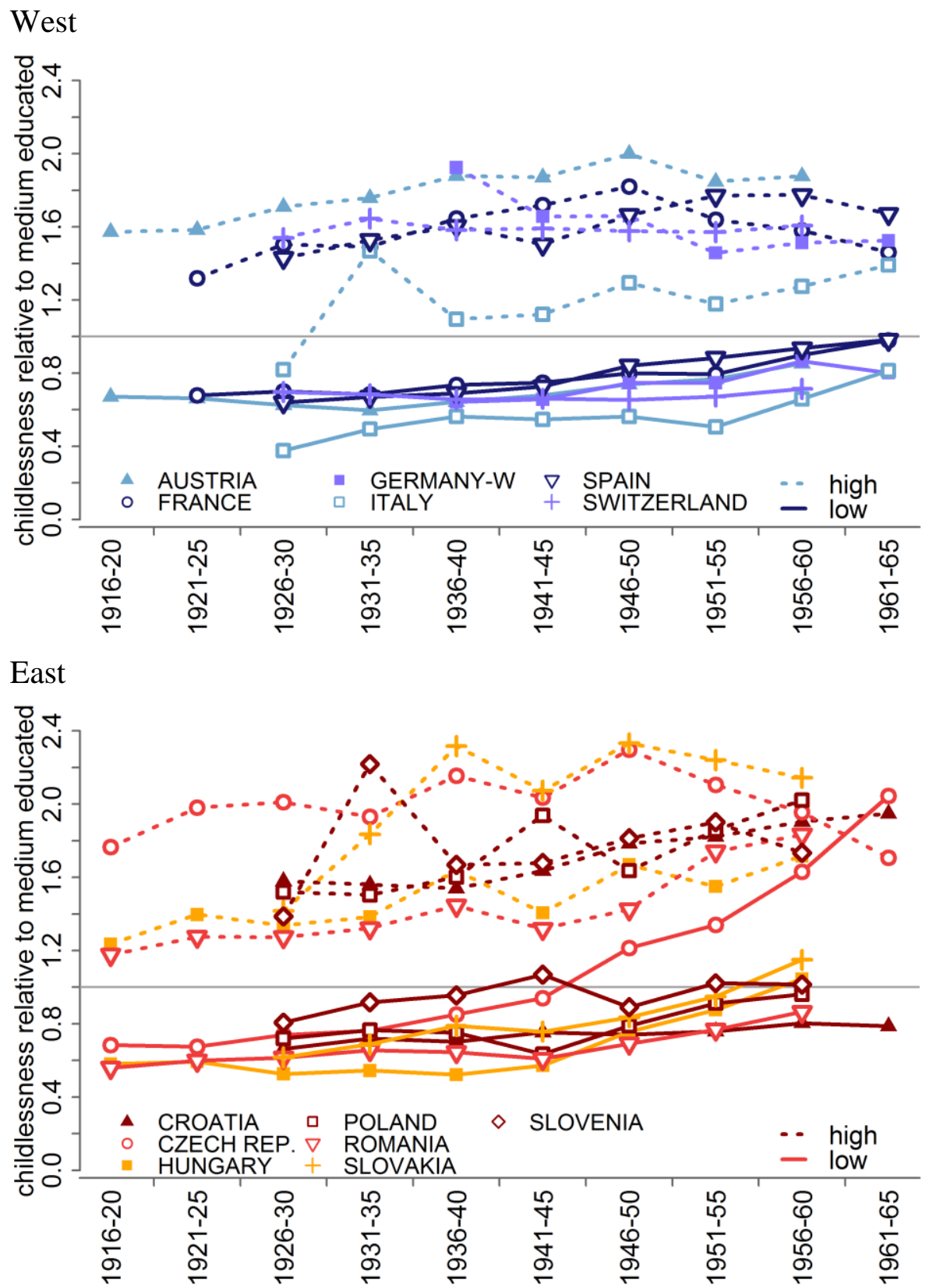

4.2 Role of Educational Structure and Education-Specific Levels of Childlessness for the Change in the Overall Level of Childlessness

We explore the role that the extensive changes in the educational structure played in the trends in childlessness, using a direct standardisation. In addition, by applying indirect standardisation we evaluate the contribution of the changes in the proportion of women remaining childless within distinct educational groups to the overall trends. 
The massive rise in educational enrolment played a surprisingly minor role in the change in childlessness levels (Figure 4). If in all the cohorts the educational structure had been the same as among women born 1936 to 1940, the share of women eventually childless would have differed from the actual one by only $15 \%$, with a positive sign in the older cohorts and a negative one in the younger ones (see Figure A2 in the Appendix for the absolute values of this difference). This number corresponds to the share explained by change in educational attainment in the US from the 1931-1939 to the 1955-1959 birth cohorts (Hayford 2013). Overall, the effect of increasing educational attainment was stable across cohorts and very similar across countries, though somewhat stronger in the most recent period in Western Europe.

In contrast, the changes in the prevalence of childlessness within educational groups (Figure 5) had a far greater impact than the changes in educational structure, though this varied by country. The massive decrease in childlessness among women born before 1936 was driven by decreasing childlessness within all the educational groups to a similar extent across the countries studied: the observed levels of childlessness in the 1916-20 birth cohort would have been up to $60 \%$ lower than the actual ones if group-specific childlessness rates had already been as low as in the 1936-40 birth cohort. The developments for the younger cohorts varied greatly across countries, however. In the German-speaking countries where childlessness increased strongly, the level of childlessness would have been lower than the observed level in the 1956-60 birth cohort by $30 \%$ had the prevalence of childlessness within educational groups remained unchanged since the 1936-40 cohort. By contrast, in France, Spain, and Italy where childlessness within educational groups started to increase much later, it would have been higher (it does not hold for the youngest cohort in Italy). Finally, in the East of Europe except for Slovakia, childlessness levels would have been higher by quite a large share if the rates had been frozen at their 1936-40 levels. The continuing decrease in childlessness in most of these countries was thus mostly due to the proportion of childless women dropping in all the educational groups. 
Figure 4 Relative difference between the actual and the directly standardised proportion of childless women (proportion of women by education kept constant)

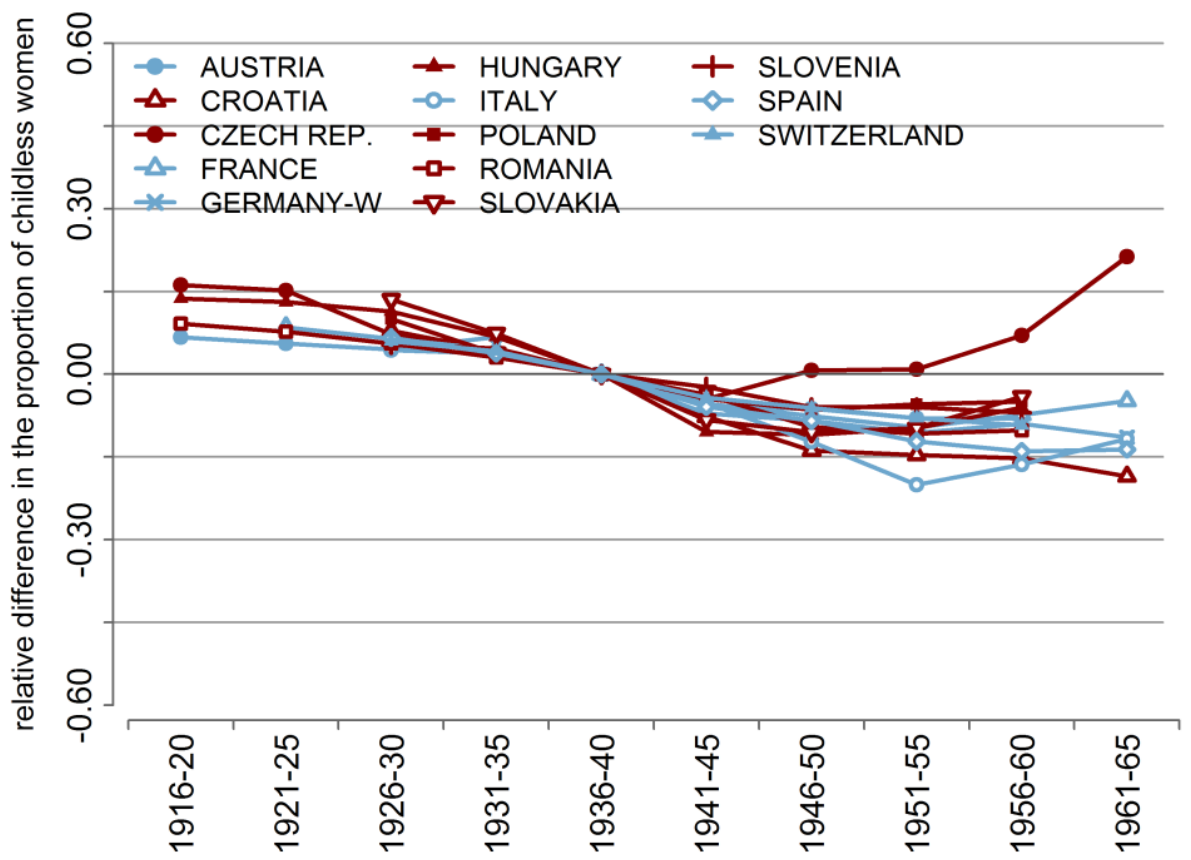

Figure 5 Relative difference between the actual and the indirectly standardised proportion of childless women (proportion of childless women kept constant)

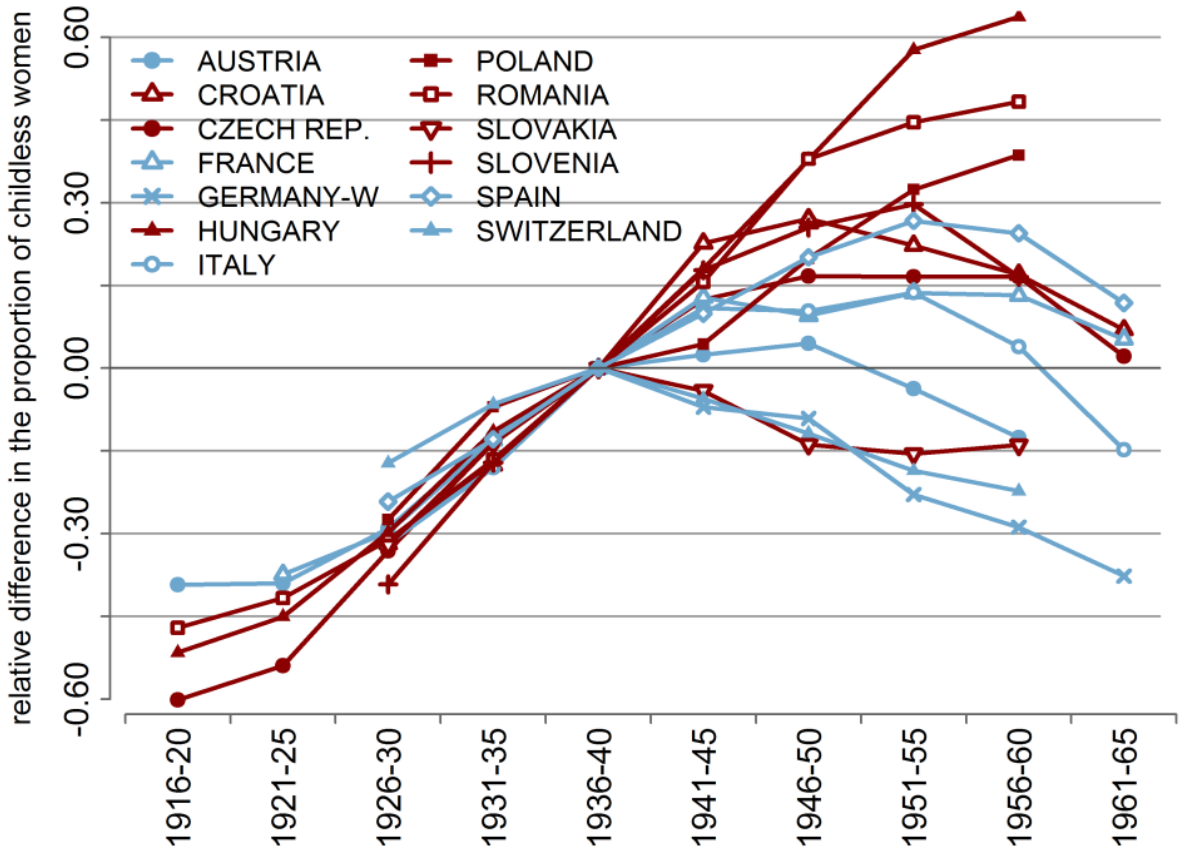




\section{Conclusion and Discussion}

Over the 20th century, cohort childlessness passed from high levels to historically low levels, thereafter increasing again in a range of countries to the high levels observed today (Rowland 2007). Despite significant differences in the social, political, and economic setup of the analysed countries, the decline was universal up to the 1936-40 birth cohorts. Only afterwards did the trends begin to diverge: in Western Europe childlessness usually started to rise, while in the East it levelled off or continued to decline. Childlessness originally exhibited a strongly positive educational gradient, which lessened across cohorts in most countries. Childlessness levels of lower and medium-educated women clearly converged, so that they are now equal in many Eastern European countries. Highly educated women so far seem to remain a distinct group despite their slowly growing share, and have become even more different from the medium-educated women in the East of Europe. The dramatic increase in female educational attainment pushed up the proportion of childless women much less than one could have expected in the second half of the century, and in the period under study the overall level of childlessness was rather driven by the childlessness trends within the educational groups.

Growing educational attainment might have played such a minor direct role in childlessness because changes have affected family formation in all educational strata. For instance, marriage has been at its highest in the baby-boom period, leaving few people behind, which could explain the universal decrease in childlessness prevalence (Van Bavel and Reher 2013). Some scholars claim that the possibility of effective contraception also encouraged career-oriented women to start a family, which contributed to the falling childlessness rates among the highly educated (Van Bavel et al. 2015). The unprecedented economic and medical development that ensured sufficient economic resources and a healthier life even in the lower social strata might have played an important role in gradually bringing fertility behaviours of less educated people closer to the other groups over the century.

We suggested originally that the growing demand for a more educated labour force and the expansion of educational attainment might have made the secondary and high education categories less selective as they absorbed people from lower strata. However, we could not provide any evidence of decreasing distinctiveness of the highly educated women in terms of childlessness, quite the opposite: there still seems to be a process of entry into motherhood specific to women with high education. It is difficult to disentangle whether highly educated women remain childless more often because the university degree and the career opportunities it opens make them postpone and/or forgo motherhood or because those who opt for staying longer in education are less family-oriented. In the cohorts under study, the changes on the labour market might have made it more difficult for highly educated women to reconcile career and childbearing, when on the other hand they were becoming less selective and more attractive on the marriage market (Esteve 2012). The comparison of the situation in the 1950s and 1960s on both sides of the Iron Curtain provides however additional information. Women from middle- and upper-class families in Western Europe and in Anglo-Saxon countries did not have to combine work and family as their husbands' jobs were stable and wages high enough to enable a family to live on the male income only (Cherlin 1983; Murphy 2002; Pfau-Effinger 2004). In the 
East, highly educated women were obliged to work as their income was indispensable but the jobs available to them were often relatively easily compatible with having children (Stloukal 1999). Thus the fact that childless women were more numerous among highly educated women both in socialist and Western countries, i.e. in completely different social and economic settings, suggests that self-selection into tertiary education could have been an important driver of the overrepresentation of childless women among the degree holders.

The gradual convergence of childlessness rates of the least educated women and of secondary school diploma holders in most countries can reflect several things. First, in time of very strong upward mobility, it might take its source in the fact that women from the lower strata partially transfer their behaviour to their newly-reached medium educational level (acculturation) (Sobel 1985). Second, it can reflect a better compatibility of their life paths and work situations with childbearing than among women who hold higher degrees. Those with secondary education benefited most from the expansion of office work, which needed educated personnel and was considered suitable for women (Cherlin 1983; Goldin 2006): middle-class women who wanted to stay in the labour market did not have to forgo marriage and motherhood. This may not have been the case in places such as the German-speaking countries where work and childbearing seemed to remain incompatible regardless of the education level (Jürgen Dorbritz and Ruckdeschel 2007; Neyer and Hoem 2009): in these countries, even medium-educated women remained constantly more likely to be childless than those without a degree.

University degree holders forwent motherhood much more often than the other groups, and this on both sides of the Iron Curtain. This finding might seem surprising because of the egalitarian rhetoric of the state-socialist regimes. However, it has been shown that while the economic/financial disparities were much smaller than in the capitalist democracies, the social inequalities and differences remained quite strong (Andorka 1995; Domański 2004; Szelenyi 1978, 1982). In both economic-political regimes, high education tended to be passed from generation to generation (Ganzeboom and Nieuwbeerta 1999) so that highly educated women might have remained a specific group fostering their social and cultural distinctiveness, which also resulted in specific family formation behaviours (Kivinen, Hedman, and Kaipainen 2007). Childlessness among highly educated women seems in fact increasingly distinct from childlessness among their medium-educated counterparts in many countries in the East. Overall levels of childlessness, however, remain much lower in the East than in the West, and even highly educated women there often still display levels below the overall levels in the West. If in childlessness, as in other family status changes, highly educated women can be considered to be forerunners of new behaviours (Lesthaeghe 2010; Ní Bhrolcháin and Beaujouan 2013), this increase among highly educated women might be the sign of a forthcoming increase in childlessness in all social strata in the East. Interestingly, the higher propensity of graduates to be childless seems to dwindle somewhat for a small number of countries in the East and West in the last birth cohorts studied, calling to mind the recent convergence and even cross-over in childlessness levels between educational groups in some Northern Europe countries (Andersson et al. 2009). 
In the later period, childlessness differences did not only grow between the East and West, but also within the West and within the East. The East shows as much diversity as the West of Europe in terms of childlessness levels and of education, and this grouping does not seem to correspond to strictly regional variations. For instance in both Romania and Hungary, education spread only late, childlessness decreased very quickly, and the educational differentials in childlessness followed quite similar paths. Poland, Slovenia, Slovakia, and the Czech Republic showed an earlier increase in level of education, low childlessness rates, and a full convergence in the levels of childlessness of low and medium-educated women. Croatia finally was somewhat in between these two groups of countries. While researchers tend to group Western European countries by policy and family behaviours (Basten, Sobotka, and Zeman 2013), little has been done to do likewise for Eastern countries (Sobotka 2011), and further studies could help filling this gap.

Our study covers the 1916-1965 birth cohorts, and childlessness rates are known to have increased further in most countries studied here during the five following one-yearcohorts (Berrington et al. 2014; Frejka 2008; Masson 2013; Miettinen et al. 2015). They might even continue to grow in the East, where they had still remained quite low (Sobotka 2005). Additionally, women are now acquiring tertiary education in most European countries to a massive extent (OECD 2014). While in the period under study, the intermediate level of education was fuelling the increase in educational attainment, in this new phase highly educated women, shown to be consistently more often childless, are becoming more numerous. In this new context one may wonder again whether the current and future increase in childlessness will be driven by the increasing share of women with tertiary education, as it seems to be the case in the UK for the 1965-69 birth cohorts (Berrington et al. 2014). It is possible that, inversely, when the share of the highly educated expands massively they start getting closer to the other groups, as seen in the most recent cohorts in France and in the US (Kravdal and Rindfuss 2008; Masson 2013). 


\section{References}

Andersson, G., M. Rønsen, L. B. Knudsen, T. Lappegård, G. Neyer, K. Skrede, K. Teschner, and A. Vikat. 2009. Cohort fertility patterns in the Nordic countries, Demographic Research 20(14) 313-352.

Anderton, D. L., N. O. Tsuya, L. L. Bean, and G. P. Mineau. 1987. Intergenerational transmission of relative fertility and life course patterns, Demography 24(4) 467-480.

Andorka, R. 1995. Changes in Hungarian Society Since the Second World War, Macalester International 2(1).

Baban, A. 1999. Romania, in H. P. David and J. Skilogianis (eds.), From abortion to contraception: a resource to public policies and reproductive behavior in Central and Eastern Europe from 1917 to the present. Westport, CT: Greenwood Press.

Barro, R. J. and J.-W. Lee. 2013. A new data set of educational attainment in the world, 19502010, Journal of Development Economics 104 184-198.

Basten, S., T. Sobotka, and K. Zeman. 2013. Future fertility in low fertility countries, Vienna Institute of Demography Working Papers 5.

Berend, I. T. 2005. What is Central and Eastern Europe?, European Journal of Social Theory 8(4) 401-416.

Berrington, A., J. Stone, and É. Beaujouan. 2014. Educational Differences in Tempo and Quantum of Childbearing in Britain: A Study of Cohorts Born 1940-1969, paper presented at the European Population Conference 2014, Budapest, Hungary, 25-28 June, accessed in May 2015 at http://epc2014.princeton.edu/papers/141064.

Bianchi, S. M. and M. A. Milkie. 2010. Work and family research in the first decade of the 21st century, Journal of Marriage and Family 72(3) 705-725.

Blau, P. M. and O. D. Duncan. 1967. The American Occupational Structure. New York: Wiley.

Bloom, D. E. and J. Trussell. 1984. What are the determinants of delayed childbearing and permanent childlessness in the United States?, Demography 21(4) 591-611.

Breen, R., R. Luijkx, W. Müller, and R. Pollak. 2009. Long-term trends in educational inequality in Europe: class inequalities and gender differences, European Sociological Review 26(1) 3148.

Brewster, K. L. and R. R. Rindfuss. 2000. Fertility and women's employment in industrialized nations, Annual Review of Sociology 26(1) 271-296.

Brzozowska, Z. 2014. Female education and fertility under state socialism : Evidence from seven Central and South Eastern European countries, paper presented at the European Population Conference, Budapest, Hungary, 25-28 June, accessed in January 2015 at http://epc2014.princeton.edu/papers/140470.

Cherlin, A. J. 1983. Changing family and household: Contemporary lessons from historical research, Annual Review of Sociology 9 51-66.

Coontz, S. 2000. "Leave it to Beaver" and "Ozzie and Harriet": American families in the 1950s, in The Way We Never Were: American Families And The Nostalgia Trap (Reprint ed, pp. 2341). New York, NY: Basic Books.

Domański, H. 2004. O ruchliwości społecznej w Polsce [On social mobility in Poland]. Warsaw: IFiS PAN. 
Dorbritz, J. and J. Fleischhacker. 1999. The Former German Democratic Republic, in H. P. David and J. Skilogianis (eds.), From abortion to contraception: a resource to public policies and reproductive behavior in Central and Eastern Europe from 1917 to the present. Westport, CT: Greenwood Press.

Dorbritz, J. and K. Ruckdeschel. 2007. Kinderlosigkeit in Deutschland — Ein europäischer Sonderweg? Daten, Trends und Gründe, in D. Konietzka and M. Kreyenfeld (eds.), Ein Leben ohne Kinder. Kinderlosigkeit in Deutschland (pp. 45-81). Wiesbaden: VS Verlag für Sozialwissenschaften.

Dykstra, P. A. and G. O. Hagestad. 2007. Childlessness and parenthood in two centuries - Different roads-different maps?, Journal of Family Issues 28(11) 1518-1532.

Esteve, A. 2012. The gender gap reversal in education and its effect on union formation: The end of hypergamy?, Population and Development Review 38 535-546.

Frejka, T. and J.-P. Sardon. 2004. Childbearing Trends and Prospects in Low-Fertility Countries: A Cohort Analysis European studies of population (Vol. 13, pp. XVI-422). Dordrecht; Boston; London: European Association for Population Studies - Kluwer Academic publishers.

Frejka, T. 1980. Fertility Trends and Policies: Czechoslovakia in the 1970s, Population and Development Review 6(1) 65-93.

Frejka, T. 2008. Overview Chapter 2. Parity distribution and completed family size in Europe: Incipient decline of the two-child family model?, Demographic Research (Special Collection 7) 19(4) 47-72.

Ganzeboom, H. B. G. and P. Nieuwbeerta. 1999. Access to education in six Eastern European countries between 1940 and 1985. Results of a cross-national survey, Communist and PostCommunist Studies 32(4) 339-357.

Giza-Poleszczuk, A. 2007. Rodzina i system społeczny [The family and the social system], in M. Marody (ed.), Wymiary życia spotecznego [The dimensions of social life]. Warsaw: Wydawnictwo Naukowe SCHOLAR.

Goldin, C. 2004. The Long Road to the Fast Track: Career and Family, Annals of the American Academy of Political and Social Science 596(1) 20-35.

Goldin, C. 2006. The quiet revolution that transformed women's employment, education, and family, The American Economic Review 96(2) 1-21.

González, M.-J. and T. Jurado-Guerrero. 2006. Remaining childless in affluent economies: a comparison of France, West Germany, Italy and Spain, 1994-2001, European Journal of Population - Revue Européenne de Démographie 22(4) 317-352.

Goujon, A. 2009. Report on changes in the educational composition of the population and the definition of education transition scenarios: The example of Italy and the Netherlands, Extended Version of Deliverable D3 in Work Package 1 (Multistate Methods) of EU (6th Framework) Funded Project MicMac: Bridging the Micro-Macro Gap in Population Forecasting.

Haney, L. A. 2002. Inventing the Needy: Gender and the Politics of Welfare in Hungary. University of California Press.

Hayford, S. R. 2013. Marriage (still) matters: the contribution of demographic change to trends in childlessness in the United States, Demography 50(5) 1641-61.

Hoem, J. M., D. Kostova, A. Jasilioniene, and C. Mureşan. 2009. Traces of the Second Demographic Transition in four selected countries in Central and Eastern Europe: Union 
formation as a demographic manifestation, European Journal of Population - Revue Européenne de Démographie 25(3) 239-255.

Inglehart, R. 1971. The Silent Revolution in Europe: Intergenerational change in post-industrial societies, The American Political Science Review 65(4) 991-1017.

Keil, T. and V. Andreescu. 1999. Fertility Policy in Ceausescu's Romania, Journal of Family History 24(4) 478-492.

Kivinen, O., J. Hedman, and P. Kaipainen. 2007. From elite university to mass higher education: Educational expansion, equality of opportunity and returns to university education, Acta Sociologica 50(3) 231-247.

Kneale, D. and H. Joshi. 2008. Postponement and childlessness: Evidence from two British cohorts, Demographic Research 19(58) 1935-1968.

Kolk, M. 2014. Understanding transmission of fertility across multiple generations - Socialization or socioeconomics?, Research in Social Stratification and Mobility 35 89-103.

Köppen, K., M. Mazuy, and L. Toulemon. 2007. Kinderlosigkeit in Frankreich, in D. Konietzka and M. Kreyenfeld (eds.), Ein Leben Ohne Kinder. Kinderlosigkeit in Deutschland (pp. 83104). VS Verlag.

Kravdal, Ø. and R. R. Rindfuss. 2008. Changing relationships between education and fertility - a study of women and men born 1940-64, American Sociological Review 73(11) 854-873.

Kreager, P. 2004. Where are the children?, in P. Kreager and E. Schroeder-Butterfill (eds.), Ageing Without Children: European and Asian Perspectives (pp. 1-45). Oxford, UK, and New York: Berghahn Books.

Kreyenfeld, M. and D. Konietzka. 2008. Education and fertility in Germany, in M. Kreyenfeld and D. Konietzka (eds.), Demographic Change in Germany (pp. 165-187). Berlin Heidelberg New York: Springer.

Lesthaeghe, R. J. 2010. The unfolding story of the second demographic transition., Population and Development Review 36(2) 211-51.

Masson, L. 2013. Avez-vous eu des enfants? Si oui, combien ?, France, Portrait Social 2013.

McIntyre, R. 1975. Pronatalist programmes in Eastern Europe, Soviet Studies 27(3) 366-380.

Miettinen, A., A. Rotkirch, I. Szalma, A. Donno, and M. L. Tanturri. 2015. Increasing childlessness in Europe: time trends and country differences, Families and Societies Working Paper Series 33 .

Morgan, S. P. 1991. Late nineteenth-and early twentieth-century childlessness, American Journal of Sociology 97(3) 779-807.

Murphy, J. 2002. Breadwinning: Accounts Of Work And Family Life In The 1950s, Labour \& Industry: A Journal of the Social and Economic Relations of Work 12(3) 59-75.

Murphy, M. 1993. The contraceptive pill and women's employment as factors in fertility change in Britain 1963-1980: a challenge to the conventional view, Population Studies 47(2) 221-43.

Neyer, G. and J. M. Hoem. 2009. Education and permanent childlessness: Austria vs. Sweden. A research note, in J. Surkyn, P. Deboosere, and J. van Bavel (eds.), Demographic Challenges for the 21st Century: A State of the Art in Demography (pp. 91-112).

Ní Bhrolcháin, M. and É. Beaujouan. 2013. Education and cohabitation in Britain: A return to traditional patterns?, Population and Development Review 39(3) 441-458. 
Nicoletti, C. and M. L. Tanturri. 2008. Differences in delaying motherhood across European countries: Empirical evidence from the ECHP, European Journal of Population - Revue Européenne de Démographie 24(2) 157-183.

OECD. 2014. Education at a Glance 2014: OECD indicators,.

Perelli-Harris, B., W. Sigle-Rushton, M. Kreyenfeld, T. Lappegård, R. Keizer, and C. Berghammer. 2010. The educational gradient of childbearing within cohabitation in Europe, Population and Development Review 36(4) 775-801.

Pfau-Effinger, B. 2004. Socio-historical paths of the male breadwinner model - An explanation of cross-national differences, British Journal of Sociology 55(3) 377-399.

Preston, S. H. 1976. Family sizes of children and family sizes of women, Demography 13(1) 10514.

Rindfuss, R. R., S. P. Morgan, and C. G. Swicegood. 1988. First Births in America: Changes in the Timing of Parenthood. University of California Press.

Rowland, D. T. 2007. Historical trends in childlessness, Journal of Family Issues 28(10) 13111337.

Sandström, G. 2014. The mid-twentieth century baby boom in Sweden - changes in the educational gradient of fertility for women born 1915-1950, The History of the Family 19(1) 120-140.

Sardon, J.-P. 2002. Recent demographic trends in the developed countries, Population (English Edition) 57(1) 111-156.

Sobel, M. E. 1981. Diagonal mobility models: A substantively motivated class of designs for the analysis of mobility effects, American Sociological Review 46(6) 893-906.

Sobel, M. E. 1985. Social mobility and fertility revisited: Some new models for the analysis of the mobility effects hypothesis, American Sociological Review 50(5) 699-712.

Sobotka, T., K. Zeman, and V. Kantorová. 2003. Demographic shifts in the Czech Republic after 1989: A Second demographic transition view, European Journal of Population 19(3) 249277.

Sobotka, T. 2005. Childless societies? Trends and projections of childlessness in Europe and the United States, paper presented at the Annual Meeting of the Population Association of America, Philadelphia, March 31- April 2, accessed in December 2014 at http://paa2005.princeton.edu/abstracts/50352.

Sobotka, T. 2008. Overview chapter 6: The diverse faces of the Second Demographic Transition in Europe, Demographic Research (Special Collection 7) 19(8) 171-224.

Sobotka, T. 2011. Fertility in Central and Eastern Europe after 1989: Collapse and gradual recovery, Historical Social Research 36(2) 246-296.

Sobotka, T. 2012. Fertility in Austria, Germany and Switzerland: Is there a common pattern?, Comparative Population Studies 36(2-3) 263-304.

Spéder, Z. and F. Kamarás. 2008. Hungary: Secular fertility decline with distinct period fluctuations, Demographic Research (Special Collection 7) 19(18) 599-664.

Stloukal, L. 1999. Understanding the "Abortion Culture" in Central and Eastern Europe, in H. P. David and J. Skilogianis (eds.), From abortion to contraception: a resource to public policies and reproductive behavior in Central and Eastern Europe from 1917 to the present. Westport, CT: Greenwood Press. 
Szelenyi, I. 1978. Social Inequalities in State Socialist Redistributive Economies - Dilemmas for social policy in contemporary socialist societies of Eastern Europe, in A. Etzioni (ed.), Policy Research (pp. 63-87). Leiden: E.J.Brill.

Szelenyi, I. 1982. The intelligentsia in the class structure of state-socialist societies, American Journal of Sociology 88 287-326.

Szołtysek, M. 2012. Spatial construction of European family and household systems: promising path or blind alley? An Eastern European perspective, Continuity and Change 27(1) 11-52.

Tanturri, M. L. and L. Mencarini. 2008. Childless or childfree? Paths to voluntary childlessness in Italy, Population and Development Review 34(1) 51-77.

Tanturri, M. L., M. Mills, A. Rotkirch, T. Sobotka, J. Takács, A. Miettinen, C. Faludi, V. Kantsa, and D. Nasiri. 2015. State-of-the-art report Childlessness in Europe, Families and Societies Working Paper Series 32.

Toulemon, L. 1996. Very few couples remain voluntarily childless, Population, an English Selection 81-27.

Van Agtmaal-Wobma, E. and M. van Huis. 2008. De relatie tussen vruchtbaarheid en opleidingsniveau van de vrouw, Bevolkingstrends 2e kwartaa 32-41.

Van Bavel, J., M. Klesment, E. Beaujouan, Z. Brzozowska, A. Puur, D. S. Reher, M. Requena, G. Sandström, T. Sobotka, and K. Zeman. 2015. Women's education and cohort fertility during the Baby Boom, paper presented at the Annual Meeting of the Population Association of America, San Diego, April 30-May 2, accessed in April 2015 at http://paa2015.princeton.edu/uploads/150211.

Van Bavel, J. and D. S. Reher. 2013. The Baby Boom and its causes: What we know and what we need to know, Population and Development Review 39(2) 257-288.

Van Bavel, J. 2014. The mid-twentieth century Baby Boom and the changing educational gradient in Belgian cohort fertility, Demographic Research 30(33) 925-962.

Van de Kaa, D. J. 1996. Anchored narratives: The story and findings of half a century of research into the determinants of fertility, Population Studies 50(3) 389-432.

Van de Kaa, D. J. 2004. Is the Second Demographic Transition a useful research concept? Questions and answers, Vienna Yearbook of Population Research 4-10.

Wood, J., K. Neels, and T. Kil. 2014. The educational gradient of childlessness and cohort parity progression in 14 low fertility countries, Demographic Research 31(46) 1365-1416.

Zeman, K., Z. Brzozowska, T. Sobotka, É. Beaujouan, and A. Matysiak. 2014. Cohort Fertility and Education Database. Methods Protocol, accessed on 18/03/2015 at http://www.eurrep.org/wpcontent/uploads/EURREP_Database_Methods_Protocol_Dec2014.pdf. 


\section{Appendix}

Figure A1 Relative childlessness index, representing childlessness level among the highly educated relative to childlessness of low-educated women in each country

West

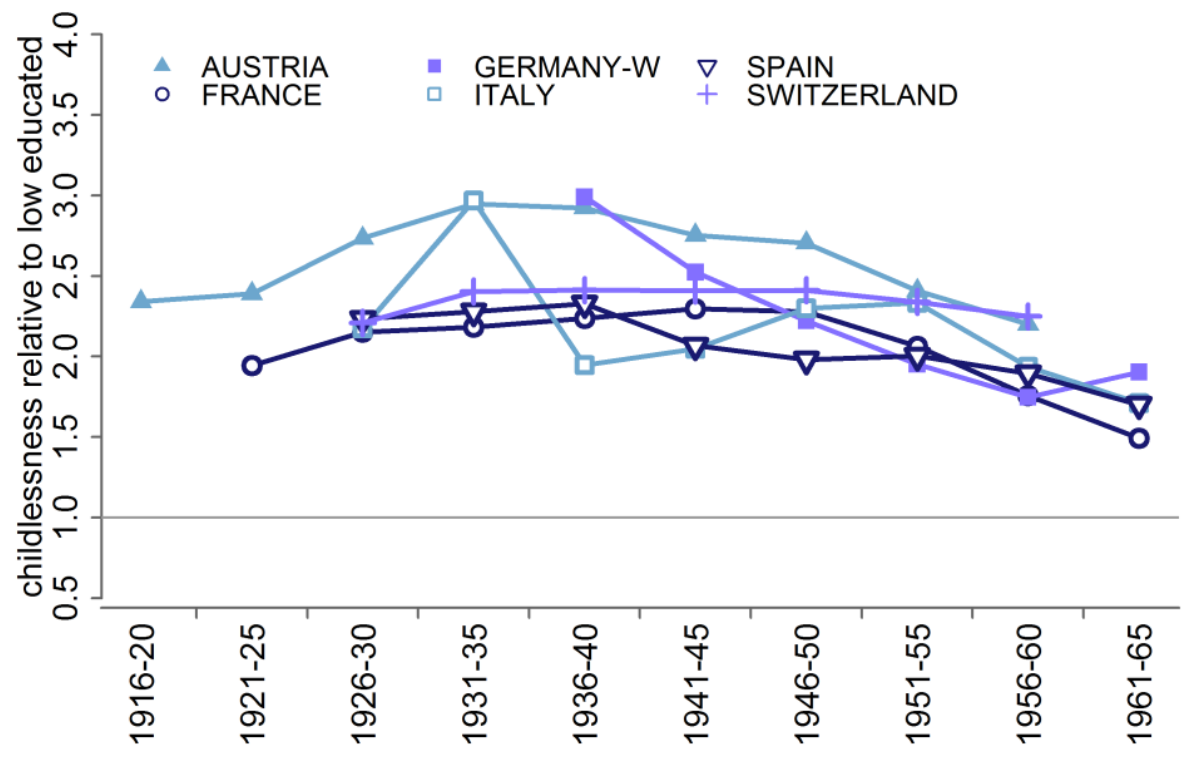

East

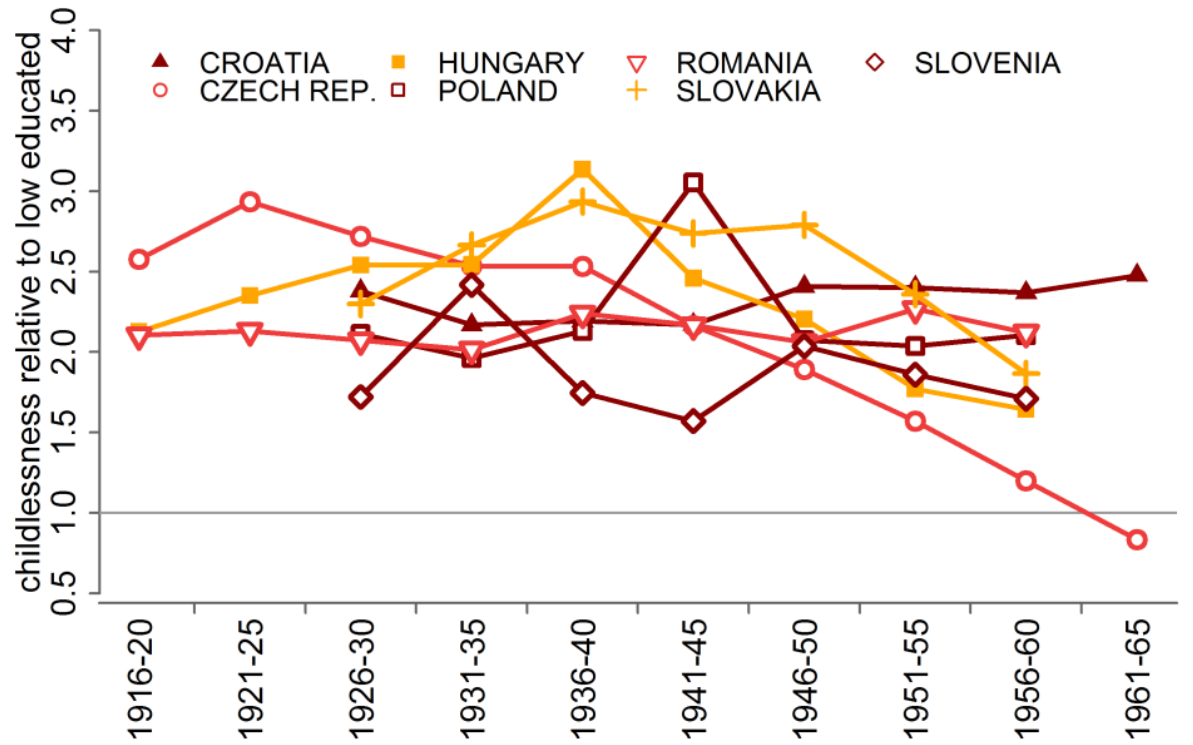


Figure A2-a Absolute difference between the real and the directly standardised proportion of childless women (proportion of women by education kept constant)

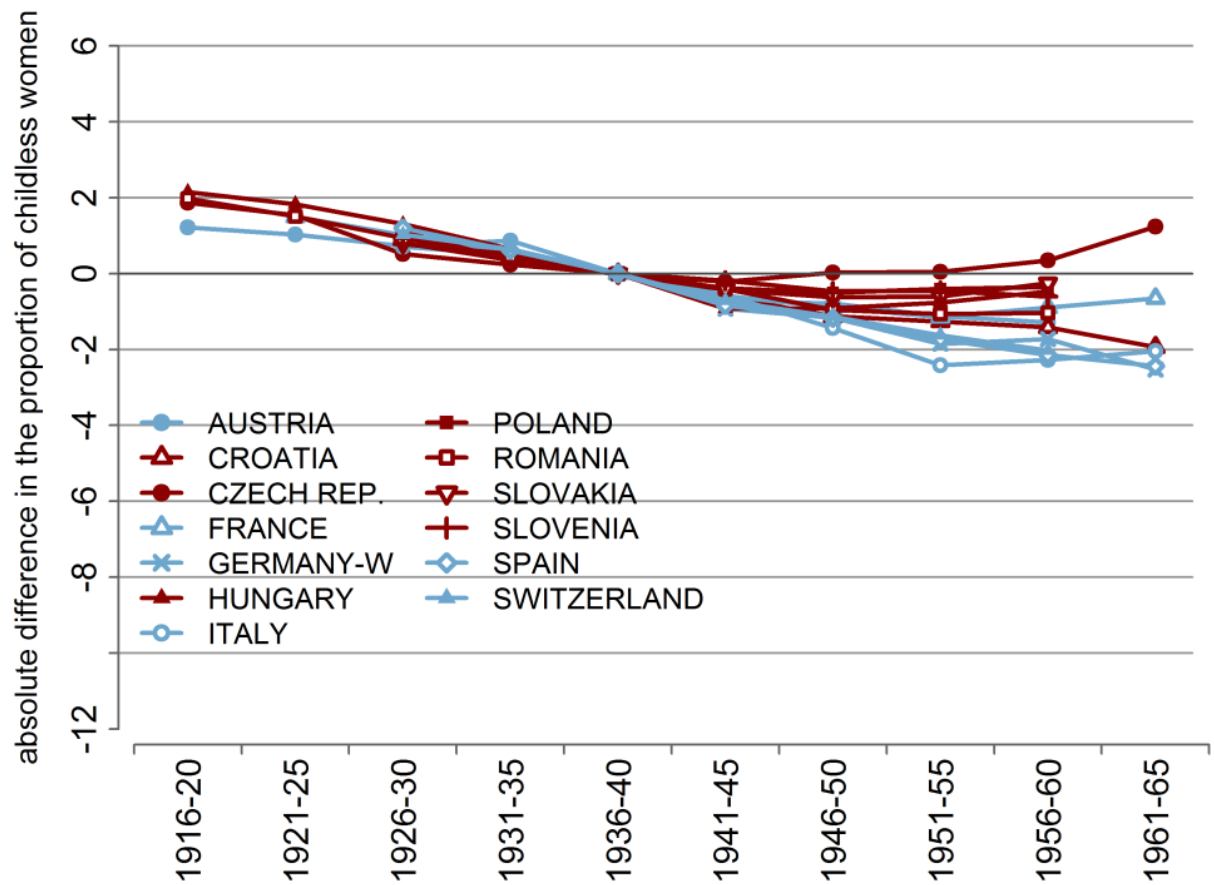

Figure A2-b Absolute difference between the real and the indirectly standardised proportion of childless women (proportion of childless women kept constant)

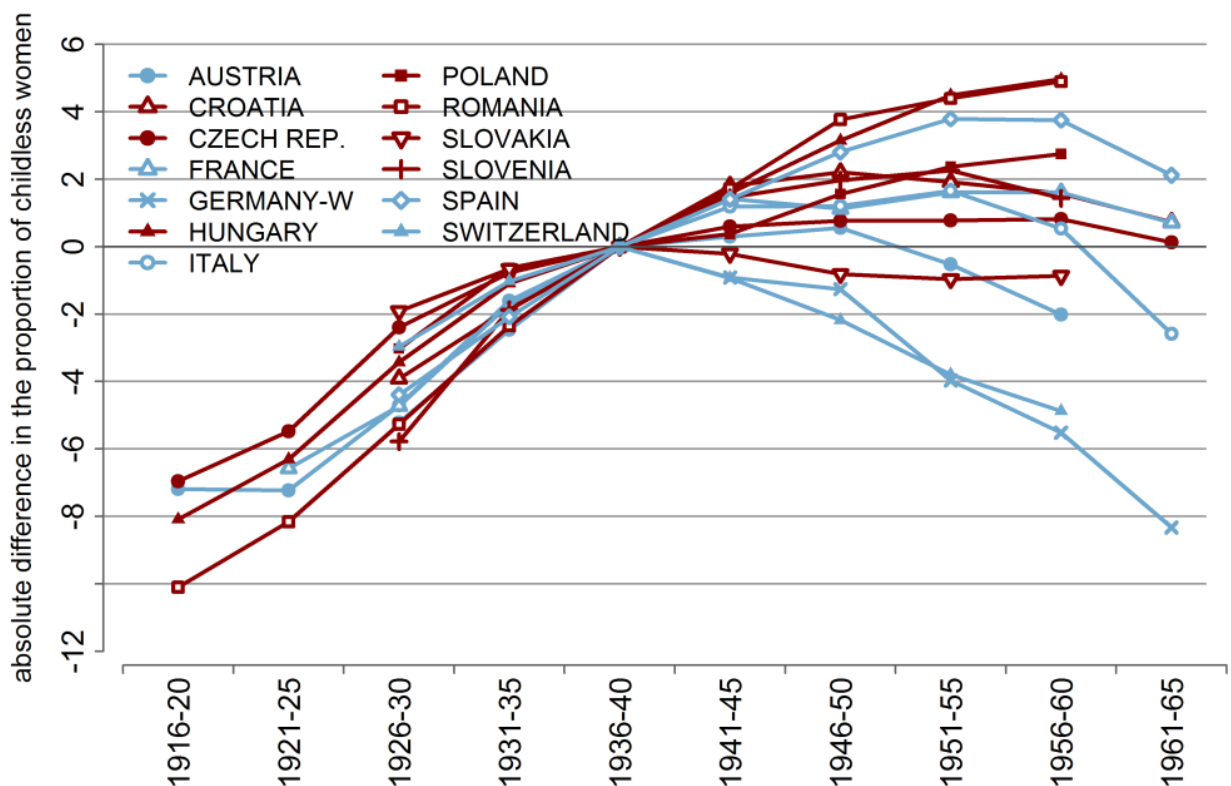


Table A1 (see attached excel file: possibly online appendix) Table of correspondence between the country education codes, Isced7 categories and the retained categorization in three levels of education

\begin{tabular}{|c|c|c|c|c|c|}
\hline Country & $\begin{array}{l}\text { Census/ } \\
\text { Survey }\end{array}$ & Years & $\begin{array}{l}\text { Original or English name of highest } \\
\text { qualification }\end{array}$ & $\begin{array}{l}\text { ISCED } 97 \\
\text { category }\end{array}$ & Category \\
\hline Austria & Census & $1991 / 2001$ & $\begin{array}{l}\text { Allgemein bildende Pflichtschule } \\
\text { Allgemein bildende höhere Schule } \\
\text { Kolleg, Abiturientenlehrgang } \\
\text { Berufsbildende höhere Schule } \\
\text { Berufsbildende mittlere Schule } \\
\text { Lehrlingsausbildung } \\
\text { Berufs- und lehrerbildende } \\
\text { Akademie } \\
\text { Universität, (Fach-)Hochschule }\end{array}$ & $\begin{array}{l}\text { ISCED2 } \\
\text { ISCED3A } \\
\text { ISCED3A4 } \\
\text { ISCED3A4 } \\
\text { ISCED3B } \\
\text { ISCED3B } \\
\text { ISCED5A6 } \\
\text { ISCED5B }\end{array}$ & $\begin{array}{l}\text { low } \\
\text { medium } \\
\text { medium } \\
\text { medium } \\
\text { medium } \\
\text { medium } \\
\text { high } \\
\text { high }\end{array}$ \\
\hline Croatia & Census & $2001 / 2011$ & $\begin{array}{l}\text { no education } \\
\text { primary 1-3rd grade } \\
\text { primary 4-7th grade } \\
\text { completed primary (8 grades) } \\
\text { basic vocational school } \\
\text { secondary vocational school } \\
\text { secondary school } \\
\text { polytechnic } \\
\text { university } \\
\text { university with diploma (Master's) } \\
\text { PhD }\end{array}$ & $\begin{array}{l}\text { ISCED0 } \\
\text { ISCED1 } \\
\text { ISCED2 } \\
\text { ISCED2 } \\
\text { ISCED3C } \\
\text { ISCED3A } \\
\text { ISCED3A } \\
\text { ISCED5B } \\
\text { ISCED5A } \\
\text { ISCED5A } \\
\text { ISCED6 }\end{array}$ & $\begin{array}{l}\text { low } \\
\text { low } \\
\text { low } \\
\text { low } \\
\text { medium } \\
\text { medium } \\
\text { medium } \\
\text { high } \\
\text { high } \\
\text { high } \\
\text { high }\end{array}$ \\
\hline $\begin{array}{c}\text { Czech } \\
\text { Republic }\end{array}$ & Census & $\begin{array}{c}1980 / 2001 / \\
2011\end{array}$ & $\begin{array}{l}\text { No education } \\
\text { Completed primary education } \\
\text { Completed lower secondary } \\
\text { (completed Elementary/Basic } \\
\text { school) } \\
\text { Vocational with certficate/diploma } \\
\text { (maturita exam) } \\
\text { Higher general secondary with } \\
\text { certificate/diploma (maturita } \\
\text { exam) } \\
\text { Higher technical secondary with } \\
\text { certificate/diploma (maturita } \\
\text { exam) } \\
\text { Post-secondary non-tertiary } \\
\text { Apprenticeship training }\end{array}$ & $\begin{array}{l}\text { ISCED01 } \\
\text { ISCED01 } \\
\text { ISCED2 } \\
\text { ISCED3AB4 } \\
\text { ISCED3AB4 } \\
\text { ISCED3AB4 } \\
\text { ISCED3AB4 } \\
\text { ISCED3C }\end{array}$ & $\begin{array}{l}\text { low } \\
\text { low } \\
\text { low } \\
\text { medium } \\
\text { medium } \\
\text { medium } \\
\text { medium }\end{array}$ \\
\hline
\end{tabular}




\begin{tabular}{|c|c|c|c|c|c|}
\hline Country & $\begin{array}{l}\text { Census/ } \\
\text { Survey }\end{array}$ & Years & $\begin{array}{l}\text { Original or English name of highest } \\
\text { qualification }\end{array}$ & $\begin{array}{l}\text { ISCED } 97 \\
\text { category }\end{array}$ & Category \\
\hline & & & $\begin{array}{l}\text { Secondary technical, without } \\
\text { certificate/diploma (maturita } \\
\text { exam) } \\
\text { Higher technical school } \\
\text { University, bachelor degree } \\
\text { University, masters degree } \\
\text { University, doctoral degree }\end{array}$ & $\begin{array}{l}\text { ISCED3C } \\
\text { ISCED5 } \\
\text { ISCED5 } \\
\text { ISCED5 } \\
\text { ISCED6 }\end{array}$ & $\begin{array}{l}\text { medium } \\
\text { high } \\
\text { high } \\
\text { high } \\
\text { high }\end{array}$ \\
\hline \multirow[t]{2}{*}{ France } & \multirow[t]{2}{*}{$\begin{array}{l}\text { Family } \\
\text { Survey }\end{array}$} & 1982 & $\begin{array}{l}\text { Aucun diplôme déclaré (no } \\
\text { diplome) } \\
\text { Primaire (primary education) } \\
\text { BEPC, BE, BEPS (lower secondary) } \\
\text { CAP, BEP... } \\
\text { Baccalauréat général, brevet } \\
\text { supérieur (higher secondary) } \\
\text { Baccalauréat technique ou } \\
\text { professionnel, brevet de lycée } \\
\text { technique } \\
\text { Diplôme des professions de la } \\
\text { santé et des professions sociales } \\
\text { (bac+2) } \\
\text { BTS, DUT, DEST (post-secondary } \\
\text { non tertiary) } \\
\text { Diplôme universitaire du premier } \\
\text { cycle, certificat de fin d'études } \\
\text { normales } \\
\text { Diplôme universitaire du deuxième } \\
\text { ou troisième cycle, CAPES (higher } \\
\text { tertiary) } \\
\text { Diplôme d'une grande école ou } \\
\text { d'école d'ingénieur }\end{array}$ & $\begin{array}{l}\text { ISCED0 } \\
\text { ISCED1 } \\
\text { ISCED2 } \\
\text { ISCED2 } \\
\text { ISCED3 } \\
\text { ISCED3 } \\
\text { ISCED4 } \\
\text { ISCED5 } \\
\text { ISCED5 } \\
\text { ISCED6 } \\
\text { ISCED6 }\end{array}$ & $\begin{array}{l}\text { low } \\
\text { low } \\
\text { low } \\
\text { low } \\
\text { medium } \\
\text { medium } \\
\text { high } \\
\text { high } \\
\text { high } \\
\text { high } \\
\text { high }\end{array}$ \\
\hline & & 1990 & $\begin{array}{l}\text { aucun diplôme } \\
\text { certificat d'études primaires } \\
\text { BEPC, brevet élémentaire, brevet } \\
\text { des collèges } \\
\text { CAP } \\
\text { BEP } \\
\text { baccalauréat général, baccalauréat } \\
\text { technologique ou professionnel, } \\
\text { brevet professionnel / technicien, } \\
\text { autre brevet, capacité en droit }\end{array}$ & $\begin{array}{l}\text { ISCED0 } \\
\text { ISCED1 } \\
\text { ISCED2 } \\
\text { ISCED3 } \\
\text { ISCED3 }\end{array}$ & $\begin{array}{l}\text { low } \\
\text { low } \\
\text { low } \\
\text { medium } \\
\text { medium }\end{array}$ \\
\hline
\end{tabular}




\begin{tabular}{|c|c|c|c|c|c|}
\hline \multirow[t]{4}{*}{ Country } & $\begin{array}{l}\text { Census/ } \\
\text { Survey }\end{array}$ & Years & $\begin{array}{l}\text { Original or English name of highest } \\
\text { qualification }\end{array}$ & $\begin{array}{l}\text { ISCED } 97 \\
\text { category }\end{array}$ & Category \\
\hline & & & $\begin{array}{l}\text { diplôme universitaire de 1er cycle, } \\
\text { BTS, DUT, diplôme des professions } \\
\text { sociales ou de la santé } \\
\text { diplôme universitaire de } 2 \text { e ou } 3 e \\
\text { cycle, diplôme d'ingénieur d'une } \\
\text { grande école }\end{array}$ & $\begin{array}{l}\text { ISCED4 } \\
\text { ISCED6 }\end{array}$ & $\begin{array}{l}\text { high } \\
\text { high }\end{array}$ \\
\hline & & 1999 & $\begin{array}{l}\text { aucun diplôme } \\
\text { certificat d'études primaires } \\
\text { BEPC, brevet élémentaire, brevet } \\
\text { des collèges } \\
\text { CAP } \\
\text { BEP } \\
\text { baccalauréat général } \\
\text { baccalauréat technologique ou } \\
\text { professionnel, brevets, capacité en } \\
\text { droit } \\
\text { diplôme universitaire de 1er cycle, } \\
\text { BTS, DUT, diplôme des professions } \\
\text { sociales ou de la santé } \\
\text { diplôme universitaire de 2e ou 3e } \\
\text { cycle, diplôme d'ingénieur d'une } \\
\text { grande école }\end{array}$ & $\begin{array}{l}\text { ISCED0 } \\
\text { ISCED1 } \\
\text { ISCED2 } \\
\text { ISCED3 } \\
\text { ISCED3 } \\
\text { ISCED3 } \\
\text { ISCED3 } \\
\text { ISCED4 } \\
\text { ISCED6 }\end{array}$ & $\begin{array}{l}\text { low } \\
\text { low } \\
\text { low } \\
\text { medium } \\
\text { medium } \\
\text { medium } \\
\text { medium } \\
\text { high } \\
\text { high }\end{array}$ \\
\hline & & 2011 & $\begin{array}{l}\text { Pas de scolarité } \\
\text { Aucun diplôme mais scolarité } \\
\text { jusqu'en école primaire ou au } \\
\text { collège } \\
\text { Aucun diplôme mais scolarité au- } \\
\text { delà du collège } \\
\text { CEP (certificat d'études primaires) } \\
\text { BEPC, brevet élémentaire, brevet } \\
\text { des collèges } \\
\text { CAP, brevet de compagnon, BEP } \\
\text { Baccalauréat général, brevet } \\
\text { supérieur } \\
\text { Baccalauréat technologique ou } \\
\text { professionnel, brevet professionnel } \\
\text { ou de technicien, BEA, BEC, BEI, } \\
\text { BEH, capacité en droit } \\
\text { Diplôme de } 1 \text { er cycle universitaire } \\
\text { BTS, DUT, diplôme des professions } \\
\text { sociales ou de la santé, } \\
\text { d'infirmier(ère) } \\
\text { Diplôme de } 2^{\circ} \text { ou } 3^{\circ} \text { cycle } \\
\text { universitaire, diplôme d'ingénieur, } \\
\text { d'une grande école, doctorat }\end{array}$ & $\begin{array}{l}\text { ISCED0 } \\
\text { ISCEDO } \\
\text { ISCED12 } \\
\text { ISCED12 } \\
\text { ISCED12 } \\
\text { ISCED3 } \\
\text { ISCED3 }\end{array}$ & $\begin{array}{l}\text { low } \\
\text { low } \\
\text { low } \\
\text { low } \\
\text { medium } \\
\text { medium }\end{array}$ \\
\hline
\end{tabular}




\begin{tabular}{|c|c|c|c|c|c|}
\hline Country & $\begin{array}{c}\text { Census/ } \\
\text { Survey }\end{array}$ & Years & $\begin{array}{l}\text { Original or English name of highest } \\
\text { qualification }\end{array}$ & $\begin{array}{l}\text { ISCED } 97 \\
\text { category }\end{array}$ & Category \\
\hline Germany & $\begin{array}{l}\text { Micro- } \\
\text { census }\end{array}$ & $2008 / 2012$ & $\begin{array}{l}\text { Universitätsabschluss / Promotion } \\
\text { Fachhochschulabschluss } \\
\text { Fachschulabschluss } \\
\text { Fachhochschul-/Hochschulreife } \\
\text { Anlern-/Lehrausbildung } \\
\text { Realschul- oder gleichwertiger } \\
\text { Abschluss } \\
\text { Haupt-(Volks-)schulabschluss } \\
\text { Ohne beruflichen } \\
\text { Ausbildungsabschluss / Ohne } \\
\text { allgemeinen Schulabschluss }\end{array}$ & $\begin{array}{l}\text { ISCED56 } \\
\text { ISCED56 } \\
\text { ISCED56 } \\
\text { ISCED34 } \\
\text { ISCED34 } \\
\text { ISCED012 } \\
\text { ISCED012 } \\
\text { ISCED012 }\end{array}$ & $\begin{array}{l}\text { high } \\
\text { high } \\
\text { high } \\
\text { medium } \\
\text { medium } \\
\text { low } \\
\text { low } \\
\text { low }\end{array}$ \\
\hline Hungary & Census & $1990 / 2001$ & $\begin{array}{l}\text { Below 1st grade } \\
\text { Primary 1-3rd grade } \\
\text { Primary 4-5th grade } \\
\text { Primary 6-7th grade } \\
\text { Primary 8th grade } \\
\text { Secondary without certificate } \\
\text { Secondary with professional } \\
\text { certificate } \\
\text { Secondary with final certificate } \\
\text { University no diploma } \\
\text { University with diploma } \\
\end{array}$ & $\begin{array}{l}\text { ISCED0 } \\
\text { ISCED1 } \\
\text { ISCED2 } \\
\text { ISCED2 } \\
\text { ISCED2 } \\
\text { ISCED2A } \\
\text { ISCED3C } \\
\text { ISCED3AB4 } \\
\text { ISCED5B } \\
\text { ISCED5A6 }\end{array}$ & $\begin{array}{l}\text { low } \\
\text { low } \\
\text { low } \\
\text { low } \\
\text { low } \\
\text { low } \\
\text { medium } \\
\text { medium } \\
\text { high } \\
\text { high } \\
\end{array}$ \\
\hline \multirow[t]{2}{*}{ Italy } & \multirow[t]{2}{*}{$\begin{array}{l}\text { Family } \\
\text { and } \\
\text { Social } \\
\text { Subjects }\end{array}$} & 2003 & $\begin{array}{l}\text { nessun titolo (non sa leggere e/o } \\
\text { scrivere) } \\
\text { nessun titolo (sa leggere e scrivere) } \\
\text { licenza elementare } \\
\text { licenza scuola media inferiore } \\
\text { diploma scuola media superiore (2- } \\
3 \text { anni) } \\
\text { diploma scuola media superiore (4- } \\
5 \text { anni) } \\
\text { diploma universitario } \\
\text { laurea } \\
\text { dottorato di ricerca o } \\
\text { specializzazione post-laurea }\end{array}$ & $\begin{array}{l}\text { ISCED01 } \\
\text { ISCED01 } \\
\text { ISCED01 } \\
\text { ISCED2 } \\
\text { ISCED3 } \\
\text { ISCED3 } \\
\text { ISCED5 } \\
\text { ISCED5 } \\
\text { ISCED6 }\end{array}$ & $\begin{array}{l}\text { low } \\
\text { low } \\
\text { low } \\
\text { low } \\
\text { medium } \\
\text { medium } \\
\text { high } \\
\text { high } \\
\text { high }\end{array}$ \\
\hline & & 2009 & $\begin{array}{l}\text { nessun titolo (non sa leggere e/o } \\
\text { scrivere) } \\
\text { nessun titolo (sa leggere e scrivere) } \\
\text { licenza elementare } \\
\text { licenza scuola media inferiore }\end{array}$ & $\begin{array}{l}\text { ISCED01 } \\
\text { ISCED01 } \\
\text { ISCED01 } \\
\text { ISCED2 }\end{array}$ & $\begin{array}{l}\text { low } \\
\text { low } \\
\text { low } \\
\text { low }\end{array}$ \\
\hline
\end{tabular}




\begin{tabular}{|c|c|c|c|c|c|}
\hline Country & $\begin{array}{l}\text { Census/ } \\
\text { Survey }\end{array}$ & Years & $\begin{array}{l}\text { Original or English name of highest } \\
\text { qualification }\end{array}$ & $\begin{array}{l}\text { ISCED } 97 \\
\text { category }\end{array}$ & Category \\
\hline & & & $\begin{array}{l}\text { diploma scuola media superiore (2- } \\
3 \text { anni) } \\
\text { diploma scuola media superiore (4- } \\
5 \text { anni) } \\
\text { accademia belle arti, istituto } \\
\text { superiore industrie artistiche, } \\
\text { accademia arte drammatica, scuola } \\
\text { interpreti e traduttori } \\
\text { diploma universitario, laurea breve } \\
\text { vecchio ordinamento, scuola } \\
\text { diretta a fini speciali, scuola } \\
\text { parauniversitaria } \\
\text { laurea di } 3 \text { anni di primo livello } \\
\text { laurea specialistica di } 2 \text { anni di } \\
\text { secondo livello } \\
\text { laurea di } 4 \text { anni o più } \\
\text { dottorato di ricerca o } \\
\text { specializzazione post-laurea }\end{array}$ & $\begin{array}{l}\text { ISCED3 } \\
\text { ISCED5 } \\
\text { ISCED5 } \\
\text { ISCED5 } \\
\text { ISCED5 } \\
\text { ISCED6 }\end{array}$ & $\begin{array}{l}\text { medium } \\
\text { high } \\
\text { high } \\
\text { high } \\
\text { high } \\
\text { high }\end{array}$ \\
\hline Poland & $\begin{array}{l}\text { Census- } \\
\text { linked } \\
\text { survey }\end{array}$ & 2002 & $\begin{array}{l}\text { Tertiary education (at least } \\
\text { doctorate) } \\
\text { Tertiary education (Master's or } \\
\text { medical degree) } \\
\text { Tertiary education (Engineer's or } \\
\text { Bachelor's degree) } \\
\text { Post-secondary school } \\
\text { Post-secondary school (no A-level } \\
\text { exam required) } \\
\text { Technical secondary school (with } \\
\text { A-Level exam) } \\
\text { Technical secondary school } \\
\text { (without A-Level exam) } \\
\text { Secondary school (with A-Level } \\
\text { exam) } \\
\text { Secondary school (without A-Level } \\
\text { exam) } \\
\text { Basic vocational school } \\
\text { Completed primary school } \\
\text { No education } \\
\text { Unknown }\end{array}$ & $\begin{array}{l}\text { ISCED6 } \\
\text { ISCED5A } \\
\text { ISCED5A } \\
\text { ISCED4 } \\
\text { ISCED4 } \\
\text { ISCED3A } \\
\text { ISCED3A } \\
\text { ISCED3A } \\
\text { ISCED3A } \\
\text { ISCED3C } \\
\text { ISCED2 } \\
\text { ISCED01 } \\
\text { Unknown }\end{array}$ & $\begin{array}{l}\text { high } \\
\text { high } \\
\text { high } \\
\text { medium } \\
\text { medium } \\
\text { medium } \\
\text { medium } \\
\text { medium } \\
\text { medium } \\
\text { medium } \\
\text { low } \\
\text { low } \\
\text { unknown }\end{array}$ \\
\hline Romania & Census & $1992 / 2002$ & $\begin{array}{l}\text { Women who have no education } \\
\text { Primary education } \\
\text { Lower secondary } \\
\text { Higher secondary - high schools }\end{array}$ & $\begin{array}{l}\text { ISCED01 } \\
\text { ISCED01 } \\
\text { ISCED2 } \\
\text { ISCED3AB4 }\end{array}$ & $\begin{array}{l}\text { low } \\
\text { low } \\
\text { low } \\
\text { medium }\end{array}$ \\
\hline
\end{tabular}




\begin{tabular}{|c|c|c|c|c|c|}
\hline Country & $\begin{array}{l}\text { Census/ } \\
\text { Survey }\end{array}$ & Years & $\begin{array}{l}\text { Original or English name of highest } \\
\text { qualification }\end{array}$ & $\begin{array}{l}\text { ISCED } 97 \\
\text { category }\end{array}$ & Category \\
\hline & & & $\begin{array}{l}\text { Higher secondary - professional } \\
\text { and apprentice } \\
\text { Post-secondary and vocational } \\
\text { education } \\
\text { Higher education - short-term } \\
\text { Higher education - long-term }\end{array}$ & $\begin{array}{l}\text { ISCED3C } \\
\text { ISCED3AB4 } \\
\text { ISCED5B } \\
\text { ISCED5A6 }\end{array}$ & $\begin{array}{l}\text { medium } \\
\text { medium } \\
\text { high } \\
\text { high }\end{array}$ \\
\hline Slovakia & Census & 2001 & $\begin{array}{l}\text { elementary } \\
\text { apprenticeship without maturita } \\
\text { vocational without maturita } \\
\text { apprenticeship with maturita } \\
\text { vocational with maturita } \\
\text { general upper secondary with } \\
\text { maturita } \\
\text { higher } \\
\text { bachelor } \\
\text { university } \\
\text { postgradual } \\
\end{array}$ & $\begin{array}{l}\text { ISCED012 } \\
\text { ISCED3C } \\
\text { ISCED3C } \\
\text { ISCED3A4 } \\
\text { ISCED3A4 } \\
\text { ISCED3A4 } \\
\text { ISCED3A4 } \\
\text { ISCED5A } \\
\text { ISCED5A } \\
\text { ISCED6 }\end{array}$ & \begin{tabular}{|l} 
low \\
medium \\
medium \\
medium \\
medium \\
medium \\
medium \\
high \\
high \\
high \\
\end{tabular} \\
\hline Slovenia & Census & 2002 & $\begin{array}{l}\text { Graduate } \\
\text { Undergraduate } \\
\text { Higher education, vocational and } \\
\text { technical } \\
\text { Secondary, general, technical, } \\
\text { professional } \\
\text { Secondary, lower and middle } \\
\text { vocational } \\
\text { Basic (primary, } 8 \text { grades) } \\
\text { None or less than basic } \\
\text { Unknown }\end{array}$ & $\begin{array}{l}\text { ISCED56 } \\
\text { ISCED56 } \\
\text { ISCED56 } \\
\text { ISCED3A } \\
\text { ISCED3C } \\
\text { ISCED2A } \\
\text { ISCED01 } \\
\text { Unknown }\end{array}$ & $\begin{array}{l}\text { high } \\
\text { high } \\
\text { high } \\
\text { medium } \\
\text { medium } \\
\text { low } \\
\text { low } \\
\text { unknown }\end{array}$ \\
\hline Spain & $\begin{array}{c}\text { Census- } \\
\text { linked } \\
\text { survey }\end{array}$ & 2011 & $\begin{array}{l}\text { Sin estudios } \\
\text { Estudios primarios o } 5 \text { cursos } \\
\text { aprobados de EGB o equivalentes } \\
\text { Bachiller Elemental, Graduado } \\
\text { Escolar, EGB completa o } \\
\text { equivalentes } \\
\text { Formacion Profesional 1er grado, } \\
\text { Oficialia Industrial } \\
\text { Formacion Profesional en } 2 \text { grado, } \\
\text { Maestria Industrial } \\
\text { Bachiller Superior, BUP } \\
\text { Otras Titulaciones medias }\end{array}$ & $\begin{array}{l}\text { ISCED01 } \\
\text { ISCED2 } \\
\text { ISCED3C } \\
\text { ISCED3B } \\
\text { ISCED3A } \\
\text { ISCED3A } \\
\text { ISCED3A }\end{array}$ & $\begin{array}{l}\text { low } \\
\text { low } \\
\text { medium } \\
\text { medium } \\
\text { medium } \\
\text { medium }\end{array}$ \\
\hline
\end{tabular}




\begin{tabular}{|c|c|c|c|c|c|}
\hline Country & $\begin{array}{l}\text { Census/ } \\
\text { Survey }\end{array}$ & Years & $\begin{array}{l}\text { Original or English name of highest } \\
\text { qualification }\end{array}$ & $\begin{array}{l}\text { ISCED } 97 \\
\text { category }\end{array}$ & Category \\
\hline & & & $\begin{array}{l}\text { Arquitecto e Ingeniero Tecnico y } \\
\text { Diplomado (aprobado completo } \\
\text { 3er curso) de Escuelas Tecnicas } \\
\text { Superiores } \\
\text { Diplomado de Escuelas } \\
\text { Universitarias y Diplomado } \\
\text { (aprobado completo 3er curso) de } \\
\text { Facultades y Colegios } \\
\text { Universitarios } \\
\text { Arquitecto o Ingeniero Superior } \\
\text { Licenciado Universitario } \\
\text { Titulaciones de Estudios Superiores } \\
\text { no universitarios } \\
\text { Doctorado } \\
\text { Titulaciones de Estudios de } \\
\text { Posgrado o Especializacion para } \\
\text { Licenciados }\end{array}$ & \begin{tabular}{|l} 
ISCED5 \\
ISCED5 \\
ISCED5 \\
ISCED5 \\
ISCED5 \\
ISCED6 \\
ISCED6
\end{tabular} & $\begin{array}{l}\text { high } \\
\text { high } \\
\text { high } \\
\text { high } \\
\text { high } \\
\text { high } \\
\text { high }\end{array}$ \\
\hline $\begin{array}{l}\text { Switzer- } \\
\text { land }\end{array}$ & Census & 2000 & $\begin{array}{l}\text { Aucune formation achevee } \\
\text { Niveau secondaire I } \\
\text { Niveau secondaire II } \\
\text { Niveau tertiaire }\end{array}$ & $\begin{array}{l}\text { ISCED01 } \\
\text { ISCED2 } \\
\text { ISCED34 } \\
\text { ISCED56 }\end{array}$ & $\begin{array}{l}\text { low } \\
\text { low } \\
\text { medium } \\
\text { high }\end{array}$ \\
\hline
\end{tabular}




\section{VIENNA INSTITUTE OF DEMOGRAPHY}

\section{Working Papers}

Abel, Guy, Estimates of Global Bilateral Migration Flows by Gender between 1960 and 2010, VID Working Paper 5/2015.

Spijker, Jeroen, Alternative Indicators of Population Ageing: An Inventory, VID Working Paper 4/2015.

Kuhn, Michael and Klaus Prettner, Population Structure and Consumption Growth: Evidence from National Transfer Accounts, VID Working Paper 3/2015.

Sobotka, Tomáš, Low Fertility in Austria and the Czech Republic: Gradual Policy Adjustments, VID Working Paper 2/2015.

Buber-Ennser, Isabella, Aspects of Gender Mainstreaming of Family and Work in Austria, VID Working Paper 1/2015.

Buber-Ennser, Isabella and Ralina Panova, Attitudes towards Parental Employment across Europe, in Australia and in Japan, VID Working Paper 5/201.

Kumar, Abhishek, Valeria Bordone and Raya Muttarak, Influence of Older Generation's Fertility Behaviours on Daughter's Desired Family Size in Bihar, India, VID Working Paper 4/2014.

Sobotka, Tomáš and Éva Beaujouan, Two is Best? The Persistence of a Two-child Family Ideal in Europe, VID Working Paper 3/2014.

Sander, Nikola, Guy J. Abel, Ramon Bauer and Johannes Schmidt, Visualising Migration Flow Data with Circular Plots, VID Working Paper 2/2014.

Barakat, Bilal, Revisiting the History of Fertility Concentration and its Measurement, VID Working Paper 1/2014.

Buber-Ennser, Isabella, Attrition in the Austrian Generations and Gender Survey, VID Working Paper 10/2013.

De Rose, Alessandra and Maria Rita Testa, Climate Change and Reproductive Intentions in Europe, VID Working Paper 09/2013.

Di Giulio, Paola, Thomas Fent, Dimiter Philipov, Jana Vobecká and Maria WinklerDworak, State of the Art: A Family-Related Foresight Approach, VID Working Paper 08/2013.

The Vienna Institute of Demography Working Paper Series receives only limited review. Views or opinions expressed herein are entirely those of the authors. 